\title{
OXIDIZED PHOSPHATIDYLCHOLINES INDUCE MULTIPLE FUNCTIONAL DEFECTS IN AIRWAY EPITHELIAL CELLS
}

Christopher D Pascoe ${ }^{1,2}$, Neilloy Roy ${ }^{1,2}$, Emily Turner-Brannen ${ }^{1,2}$, Alexander Schultz ${ }^{1,2}$, Jignesh Vaghasiya ${ }^{1,2}$, Amir Ravandi $^{1,3}$, Andrew J Halayko ${ }^{1,2}$, Adrian R West ${ }^{1,2}$

1, Department of Physiology and Pathophysiology, University of Manitoba, MB, Canada

2, Biology of Breathing Group, Children's Hospital Research Institute of Manitoba, MB, Canada

3, Institute of Cardiovascular Sciences, St. Boniface Hospital Albrechtsen Research Centre, MB Canada

\section{Correspondence}

Dr Adrian R West

Children's Hospital Research Institute of Manitoba

606A John Buhler Research Centre

715 McDermot Avenue

Winnipeg MB R3E 3P4

Canada

Email: adrian.west@umanitoba.ca

Phone: +1 2047893603

\section{Grants}

1. Natural Sciences and Engineering Research Council, Discovery Grant (Adrian West)

2. Research Manitoba, New Investigator Operating Grant (Adrian West)

3. Research Manitoba, Postdoctoral Fellowship (Christopher Pascoe)

4. Canadian Respiratory Research Network, Postdoctoral Fellowship (Christopher Pascoe)

5. Canadian Institutes of Health Research, Banting Postdoctoral Fellowship (Christopher Pascoe)

6. Research Manitoba and CHRIM, Graduate Studentship (Neilloy Roy)

7. Research Manitoba and CHRIM, Graduate Studentship (Jignesh Vaghasiya)

8. Canada Research Chairs Program (Andrew Halayko)

9. Canadian Institutes of Health Research Emerging Network: Canadian Respiratory Research Network (Andrew Halayko)

The grant bodies had no role in study design, data collection and analysis, decision to publish, or preparation of the manuscript.

\section{Short Title}

Oxidized phosphatidylcholines impair epithelial barrier

\section{Keywords}

Airway epithelium

Epithelial barrier

Wound healing

Oxidative stress

Lipid peroxide 
bioRxiv preprint doi: https://doi.org/10.1101/823666; this version posted October 26, 2020. The copyright holder for this preprint (which was not certified by peer review) is the author/funder, who has granted bioRxiv a license to display the preprint in perpetuity. It is made available under Oxidized phosphatidylcholines impair epithelial barrier

\section{ABSTRACT}

Oxidative stress is a hallmark of numerous airway diseases, contributing to extensive cell and tissue damage. Cell membranes and the airway mucosal lining are rich in phospholipids that are particularly susceptible to oxidative attack, producing bioactive molecules including oxidized phosphatidylcholines (OxPC). With the recent discovery of elevated OxPC in asthmatic patients after allergen challenge, we hypothesized that OxPC directly contribute to disease by inducing airway epithelial cell dysfunction.

We found that OxPC induced dose-dependent cell stress and loss of viability in BEAS-2B and Calu-3 cell lines and primary human epithelial cells. These responses corresponded with significant epithelial barrier dysfunction, which was further compounded when combining OxPC with an epithelial wound. OxPC inhibited DNA synthesis and migration required to re-establish barrier function, but cells recovered if OxPC were washed off soon after treatment. OxPC induced generation of reactive oxygen species, lipid peroxidation and mitochondrial dysfunction, raising the possibility that OxPC cause pathological lipid metabolism in a selfpropagating cycle. The oxidative stress induced by OxPC could not be abrogated by putative OxPC receptor blockers, but partial recovery of barrier function, proliferation and lipid peroxidation could be achieved with the antioxidant $n$-acetyl cysteine.

In summary, we have identified OxPC as a group of bioactive molecules that significantly impair multiple facets of epithelial cell function, consistent with pathological features of asthma. Further characterisation of the mechanisms by which OxPC affect epithelial cells could yield new insights into how oxidative stress contributes to the pathogenesis of airway disease.

\section{INTRODUCTION}

Asthma is a chronic disease of the airways which is characterized by inflammation, structural cell dysfunction, and excessive airway narrowing. Many of the features of asthma have been linked to reactive oxygen species (ROS) produced endogenously and upon exposure to environmental insults including air pollution, allergens, and smoke (49). ROS cause damage to tissues and cellular components and can act as a potent promoter of pro-inflammatory signals $(45,65,66)$. Indeed, in airway epithelial cells, ROS enhances IL-8 production and reduces the activity of HDAC2 (30), which has been linked with steroid refractoriness in asthma (9, 37). Protein levels of glutathione peroxidase and superoxide dismuatase, two prominent antioxidant enzymes in the lung, are reduced in children with asthma (48). Further, the plasma levels of lipid peroxide markers of oxidative stress were increased in people with asthma, especially so in individuals with the glutathione-s-transferase $\mathrm{val} / \mathrm{val}$ genotype (12). Finally, the abundance of ROS in the serum of patients with asthma is correlated with the 
bioRxiv preprint doi: https://doi.org/10.1101/823666; this version posted October 26, 2020. The copyright holder for this preprint (which was not certified by peer review) is the author/funder, who has granted bioRxiv a license to display the preprint in perpetuity. It is made available under Oxidized phosphatidylcholines impair epithelial barrier

degree of airway hyperresponsiveness (AHR) and acute exacerbations of asthma requiring hospitalization (8, 16).

ROS are capable of damaging lipid membranes and the lipid-rich mucosal lining of the airways resulting in the production of a group of potent pro-inflammatory molecules collectively known as oxidized phosphatidylcholines, or OxPC (4). OxPC are produced from the poly-unsaturated fatty acid tails of arachidonoyl and linoleoyl phospholipids to form OxPAPC and OxPLPC respectively (20). In disease, OxPC promote the induction of atherogenic pathways in endothelial cells $(22,35)$, and can modulate either enhancement or impairment of endothelial barrier function depending on the disease context $(3,33,51)$. OxPC are also associated with inflammatory pain, mediated by transient receptor potential channels TRPA1 and TRPV1 (40). In the lung, OxPC have been identified in mice and humans following infection with influenza and Mycobacterium $(10,36,55)$ and in the bronchoalveolar lavage fluid of patients with asthma (41). Some literature suggests that low doses of OxPC can act as inhibitors of toll-like receptor (TLR) signaling (13) however most research agrees that at pathophysiological concentrations, they act as mediators of inflammation and disease $(21,44)$. Recently, it has been shown in cultured human airway smooth muscle cells that OxPC promote inflammation characterized by IL-6, IL-8, GM-CSF secretion and the production of pro-inflammatory lipid mediators, and that OxPC induce airway narrowing in murine thin cut lung slices (41).

The airway epithelial cell plays an important role in protecting the underlying tissue from environmental irritants and coordinating inflammatory responses against microbes, and it is well established that dysfunction in the airway epithelium is an important factor asthma pathogenesis (28). With the recent identification of OxPC in the lungs of people with asthma and their well-established role in modulating endothelial cell function in blood vessels, we sought to establish their role in asthma pathogenesis through their ability to disrupt airway epithelial cell function. This manuscript is the first to show that OxPC promote airway epithelial cell dysfunction by disrupting their ability to form a protective barrier and impairing their self-repair capacity. Moreover, OxPC promote ongoing oxidative stress evidenced by the production of additional ROS and lipid peroxides, as well as mitochondrial dysfunction, consistent with the pathological features of asthmatic epithelium.

\section{METHODS}

\section{Cell Culture}

Calu-3 human airway epithelial cells were purchased from ATCC (HTB-55). Cells were propagated in DMEM/F12 (Gibco 11330057) supplemented with 10\% heat inactivated fetal bovine serum (FBS) (Gibco 12483020) and 1\% penicillin/streptomycin (Gibco 15140122). For all experiments, Calu-3 were trypsinized and re-seeded at a 
bioRxiv preprint doi: https://doi.org/10.1101/823666; this version posted October 26, 2020. The copyright holder for this preprint (which was not certified by peer review) is the author/funder, who has granted bioRxiv a license to display the preprint in perpetuity. It is made available under Oxidized phosphatidylcholines impair epithelial barrier

density of $2 \times 10^{5}$ cells $/ \mathrm{cm}^{2}$ onto Transwell membranes [12 mm diameter, $0.4 \mu \mathrm{m}$ pore size (Corning 3460)], or $18 \mathrm{~mm}$ round glass coverslips (VWR CA48382-041), 12-well plates (Sarstedt 83.3921), or Seahorse XF24 microplates (Agilent 100777-004) coated with $3 \mu \mathrm{g} / \mathrm{mL}$ rat tail collagen I (Corning 354236) in PBS. Cells were maintained in growth media for 4 days before being serum-deprived for 48 hours in DMEM/F12 containing $0.5 \% \mathrm{FBS}$ and $1 \%$ insulin-transferrin-selenium (ITS) supplement (Gibco 41400045).

Normal human bronchial epithelial cells were purchased from Lonza (CC-2540S, single donor, lot \# 493462) and grown in PneumaCult ${ }^{\mathrm{TM}}$-Ex Plus Medium (Stemcell Technologies 05040). Cells at passage 2-3 were trypsinized and re-seeded onto 12-well plates (nHBE) or Transwells (ALI-nHBE) at a density of $1 \times 10^{5} \mathrm{cells} / \mathrm{cm}^{2}$ and maintained in PneumaCult ${ }^{\mathrm{TM}}$-Ex Plus for 3-4 days. ALI-nHBE cells were then transferred to fully supplemented PneumaCult ${ }^{\mathrm{TM}}$-ALI Medium, exposed to an air-liquid interface, and maintained for $\geq 3$ weeks for mucociliary differentiation, confirmed by the presence of mucus, ciliary activity, and establishment of epithelial barrier function $\left(>500 \Omega . \mathrm{cm}^{2}\right)$.

BEAS-2B-GRE cells [gift from Dr. Rob Newton, previously described previously in (7)] were propagated in DMEM/F-12 supplemented with $10 \%$ FBS and $100 \mu \mathrm{g} / \mathrm{mL} \mathrm{G} 418$, and seeded at a density of $3 \times 10^{3}$ cells $/ \mathrm{cm}^{2}$ in 12 -well plates. Cells were grown until approximately $80 \%$ confluent then serum deprived for 24 hours in DMEM/F12 with $1 \%$ ITS.

\section{Generation and Administration of Oxidized Lipids}

OxPC were generated as described previously (62). In brief, PAPC (1-palmitoyl-2-arachidonoyl-sn-glycero-3phosphocholine, Avanti Polar Lipids 850459C) was exposed to room air for 3-4 days, during which PAPC visibly changed from a white to yellow paste. PAPC rapidly oxidizes in cell culture conditions, thus the non-oxidizable PSPC (1-palmitoyl-2-stearoyl-sn-glycero-3-phosphocholine, Avanti Polar Lipids 850456C) was used as a negative control . Treated OxPC/PSPC were resuspended in chloroform:methanol $(2: 1)$ at $1 \mathrm{mg} / \mathrm{mL}$ and stored at $-20^{\circ} \mathrm{C}$ under nitrogen gas to prevent further oxidation.

OxPC and PSPC were prepared for dosing by aliquoting an appropriate volume of lipid solution and evaporating the chloroform:methanol under a stream of sterile nitrogen. The remaining lipid was immediately resuspended in warm media or buffer as appropriate and added to the cells (Calu-3 on Transwells: $1 \mathrm{~mL}$ basolateral chamber, $0.5 \mathrm{~mL}$ apical chamber; Calu-3, nHBE and BEAS-2B-GRE in 12-well plates: $1 \mathrm{~mL}$; Calu-3 in Seahorse plates: $500 \mu \mathrm{L}$; ALI-nHBE on Transwells, $1 \mathrm{~mL}$ basolateral chamber, $75 \mu \mathrm{L}$ apical chamber). For exposure times exceeding 3 days, cells were re-dosed with OxPC/PSPC in fresh media every 3-4 days. Apical OxPC and control treatments did not have any observable effect on the ciliary motion or mucus secretion of ALI-nHBE. 
bioRxiv preprint doi: https://doi.org/10.1101/823666; this version posted October 26, 2020. The copyright holder for this preprint (which was not certified by peer review) is the author/funder, who has granted bioRxiv a license to display the preprint in perpetuity. It is made available under Oxidized phosphatidylcholines impair epithelial barrier

\section{Cell Stress and Viability}

Cell stress was assessed by LDH release using the Roche Cytotoxicity Detection Kit (Roche 11644793001) in cells treated with OxPC $(0-160 \mu \mathrm{g} / \mathrm{mL})$ or PSPC $(160 \mu \mathrm{g} / \mathrm{mL})$ for 24 hours. Culture media was collected, gently centrifuged ( $150 \times$ RCF for 4 minutes) and combined with the kit reagent for $10 \mathrm{~min}$ before absorbance readings were taken at $490 \mathrm{~nm}$. LDH release was expressed as the percentage of LDH activity in the media relative to untreated control cells lysed with $2 \%$ triton X-100 (Sigma X-100).

Cell viability was determined by the uptake and retention of neutral red dye. After 24-hour exposure to OxPC or PSPC, a $0.33 \%$ stock solution of neutral red (Sigma N7005) in PBS was added 1:20 to the culture media and incubated for 2 hours. Cells were then gently rinsed with PBS and lysed in four times the original culture media volume with a solution of $1 \%$ acetic acid and $50 \%$ ethanol in $\mathrm{H}_{2} \mathrm{O}$. Net absorbance was then calculated as $\mathrm{A}_{540}$ minus $A_{690}$.

\section{Epithelial Barrier Function}

The effect of OxPC on epithelial barrier function in Calu-3 and ALI-nHBE under static and scratched conditions was determined by measuring paracellular permeability and transepithelial electrical resistance (TEER).

Paracellular permeability $(P, \mathrm{~cm} / \mathrm{s})$ was calculated using the steady state approximation equation for Transwells (5):

$$
P=\frac{\Delta C_{B}}{\Delta t}\left(\frac{V_{B}}{A \cdot C_{A}}\right)
$$

In brief, Transwells (surface area $A=1.13 \mathrm{~cm}^{2}$ ) were treated with OxPC or PSPC for 24 hours, washed with PBS, and the apical chamber loaded with $0.5 \mathrm{~mL}$ of $300 \mu \mathrm{g} / \mathrm{mL}\left(C_{A}\right)$ of sterile sodium fluorescein (NaFlu) (Sigma F6377) in Hank's Balanced Salt Solution (HBSS) (Gibco 14065056). Assessment was initiated by transferring Transwells to fresh 12-well plates containing $1.5 \mathrm{~mL}\left(V_{B}\right)$ per well HBSS, and monitoring NaFlu accumulation in the basolateral chamber at $37^{\circ} \mathrm{C}$ for 3 hours in a FLUOstar Optima fluorescence plate reader in orbital average mode (7 locations, 22 mm diameter, Ex: $460 \mathrm{~nm}$ Em: $520 \mathrm{~nm}$ ). Fluorescence time curves for each Transwell were converted to basolateral concentration $\left(C_{B}, \mu \mathrm{g} / \mathrm{mL}\right)$ time curves using a fluorescence-concentration standard curve. The slope of the linear segment of these concentration-time curves $\left(\Delta C_{B} / \Delta t, \mu \mathrm{g} / \mathrm{mL} / \mathrm{s}\right)$ was then determined using the linear regression function of GraphPad Prism 6.07.

TEER was measured with a freshly calibrated MilliCell ERS-02 Voltohmmeter (Millipore). Baseline TEER was measured in PBS prior to cell seeding and subtracted from all experimental measurements, and net TEER was normalized to an equivalent untreated and non-scratched control to account for temporal variability. To assess 
bioRxiv preprint doi: https://doi.org/10.1101/823666; this version posted October 26, 2020. The copyright holder for this preprint (which was not certified by peer review) is the author/funder, who has granted bioRxiv a license to display the preprint in perpetuity. It is made available under Oxidized phosphatidylcholines impair epithelial barrier

barrier recovery after a wound, cells were scratched with a sterile $10 \mu \mathrm{L}$ pipet tip and firm pressure, washed once with PBS, and post-wound TEER readings taken. Cells were then treated with media containing OxPC or PSPC as appropriate, and TEER monitored for up to 7 days.

\section{DNA synthesis as a metric of proliferation}

DNA synthesis was assessed by thymidine-analog incorporation and histological detection using the Click-iT EdU Imaging Kit (Thermo Fisher C10337). Confluent serum-deprived Calu-3 cells on coverslips were scratched, washed, and incubated with OxPC ( $80 \mu \mathrm{g} / \mathrm{mL})$ for up to 48 hours before being pulsed with $10 \mu \mathrm{M}$ 5-ethynyl-2'deoxyuridine (EdU) for 2 hours. The cells were then fixed with 4\% paraformaldehyde (PFA) in PBS for 15 minutes, washed twice with 3\% BSA in PBS and permeabilized with 0.5\% triton X-100 in PBS for 20 minutes. EdU fluorescent labelling was performed per the manufacturers instruction's before nuclei were counterstained with $0.2 \mu \mathrm{g} / \mathrm{mL}$ Hoechst 33342 (Thermo Fisher H1399) in PBS for 10 minutes. Coverslips were mounted with SlowFade Diamond (Thermo Fisher S36967) before being sealed with nail varnish and imaged on an Olympus IX-51 fluorescent microscope. Images of at least 3 fields from each coverslip (minimum 1000 cells per ' $n$ ') were captured at the same time with consistent exposure settings, before EdU positive and total nuclei were manually counted with ImageJ.

\section{mRNA abundance}

The mRNA abundance for epithelial phenotype markers was assessed by RT-qPCR. Calu-3 were treated with OxPC or PSPC for 18 hours before total RNA was isolated by the Ambion Purelink RNA Mini Kit (Thermo Fisher 12183025) before RNA concentration and purity were assessed by $A_{260}: A_{280}$ spectrophotometry. Reverse transcription was performed with $1 \mu \mathrm{g}$ total RNA using iScript Reverse Transcription Supermix for RT-qPCR (BioRad 170-8841). cDNA equivalent to 20 ng of total RNA was then amplified in duplicate using SsoAdvanced Universal SYBR Green Supermix (Bio-Rad 172-5274) and $300 \mathrm{nM}$ of the appropriate primers (Table 1) in a BioRad CFX96 thermal cycler. Cycling conditions involved $30 \mathrm{~s}$ incubation at $95^{\circ} \mathrm{C}$ for polymerase activation, followed by 40 cycles of denaturing at $95^{\circ} \mathrm{C}$ for $10 \mathrm{~s}$ and annealing/extension at $58^{\circ} \mathrm{C}$ for $30 \mathrm{~s}$. Crossing thresholds $(\mathrm{Ct})$ were calculated and housekeeping gene stability confirmed ( $\mathrm{M}$ value $<0.25$ ) using the Bio-Rad CFX Manager 3.1 software, and mean reaction efficiency (E) was determined using LinRegPCR 2017.0 (46). Relative mRNA abundance was calculated using efficiency-corrected $\Delta \mathrm{Ct}\left(\mathrm{E}^{\Delta \mathrm{Ct}}\right)$ divided by a normalizing factor (NF) derived from the geometric mean of $E^{\Delta C t}$ for no less than two stable housekeeping genes $(26,56)$. The final data was scaled such that untreated control condition presented a mean result of $1 \mathrm{AU}$. 
bioRxiv preprint doi: https://doi.org/10.1101/823666; this version posted October 26, 2020. The copyright holder for this preprint (which was not certified by peer review) is the author/funder, who has granted bioRxiv a license to display the preprint in perpetuity. It is made available under Oxidized phosphatidylcholines impair epithelial barrier

\section{Oxidative Stress}

The capacity of OxPC and house dust mite extract (HDM, Greer XPB82D3A2.5) to induce the accumulation of general cytosolic ROS, cytosolic superoxide and mitochondrial superoxide in Calu-3 were assessed by $2^{\prime}, 7^{\prime}$ dichlorofluorescin diacetate (DCF), dihydroethidium (DHE) and MitoSOX assays respectively. For DCF assays, serum-deprived Calu-3 were loaded with 10 $\mu$ M DCF (Sigma D6883) in low-serum media for 30 minutes, then washed with warm Hanks Balanced Salt Solution (HBSS). Cells were then incubated with OxPC, PSPC, HDM (100 $\mu \mathrm{g} / \mathrm{mL}$ ) or positive control cumene hydroperoxide (cumene- $\mathrm{OOH}, 200 \mu \mathrm{M}$ ) in HBSS, and fluorescence quantified in a FLUOstar Optima (Ex 492, Em 520) for 2 hours.

For DHE and MitoSOX assays, cells were pre-incubated with OxPC, PSPC, or positive controls doxorubicin (50 $\mu \mathrm{M}$; New England Biolabs 5927) and antimycin A (10 $\mu \mathrm{M}$; Sigma-Aldrich A8674) for 2 hours in low-serum media. Cells were then stained with $5 \mu \mathrm{M}$ DHE (Thermo Fisher D1168) for 30 minutes or $5 \mu \mathrm{M}$ MitoSOX (Thermo Fisher M36008) for 15 minutes and counterstained with H33342 for 10 minutes. Fluorescence intensity was quantified in a FLUOstar Optima (DHE and MitoSOX: Ex 485, Em 590), and cells were imaged by fluorescence microscopy. Exposure was set using the appropriate positive control condition, and all images were taken at the same time at consistent settings.

\section{Lipid Peroxidation Assays}

The generation of lipid peroxides in response to OxPC- and HDM-induced-ROS was quantitatively assessed in Calu-3 with the Image-iT Lipid Peroxidation Kit (Thermo Fisher C10445). Calu-3 cells were loaded with $10 \mu \mathrm{M}$ BODIPY-C11 in HBSS for 30 minutes, washed three times with PBS, and treated with OxPC, PSPC, HDM (100 $\mu \mathrm{g} / \mathrm{mL}$ ) or cumene-OOH in HBSS for $2 \mathrm{hr}$. The progress of lipid peroxidation was monitored as the ratio of oxidized to reduced BODIPY-C11 at $37^{\circ} \mathrm{C}$ for 2 hours in a Cytation 5MPV (fluorescence intensity $5 \times 5$ area scanning, Oxidized Ex: 478/20 nm Em 520/20 nm, Reduced Ex: 566/20 nm Em 606/20 nm).

To confirm lipid peroxidation and subsequent protein oxidization, the Click-iT Lipid Peroxidation Imaging Kit (Thermo Fisher C10446) was used. Calu-3 cells were simultaneously loaded with $50 \mu \mathrm{M}$ linoleamide alkyne (LAA) and treated with OxPC in HBSS for 2 hours. Cells were then washed with PBS, fixed in 4\% PFA for 15 minutes then permeabilized in 4\% PFA with $0.5 \%$ triton X-100. After 3 washes in PBS cells were blocked with 1\% BSA for 30 minutes and LAA fluorescent labelling was performed per the manufacturer's instructions. Cells were then counterstained, mounted and imaged as described above. 
bioRxiv preprint doi: https://doi.org/10.1101/823666; this version posted October 26, 2020. The copyright holder for this preprint (which was not certified by peer review) is the author/funder, who has granted bioRxiv a license to display the preprint in perpetuity. It is made available under Oxidized phosphatidylcholines impair epithelial barrier

\section{Mitochondrial Function}

Mitochondrial membrane potential was assessed in live cells using the fluorescent dye tetramethylrhodamine (TMRM; Biotium 70017). Briefly, Calu-3 were treated with OxPC or PSPC for 2-hours and then stained with 0.1 $\mu \mathrm{M}$ TMRM in HBSS for 30-minutes. The oxidative phosphorylation uncoupler CCCP ( $2 \mu \mathrm{M}$, Sigma C2759) was used as a negative control to establish baseline/minimal mitochondrial membrane potential. Excess TMRM dye was removed with HBSS and the degree of fluorescence intensity relative to the CCCP condition was measured in a FLUOstar Optima (Ex 548, Em 573 nm).

Oxygen consumption rate (OCR) was measured during Seahorse XF Cell Mito Stress Tests as per the user guide (Agilent 103015-100) with modifications. In brief, Calu-3 in Seahorse plates were switched to Seahorse XF base media (Agilent 103334-100) supplemented with 10 mM glucose (Fisher BP350), 1 mM sodium pyruvate (Gibco 11360070) and 2 mM Glutamax (Gibco 35050061) and treated with OxPC such that the first baseline OCR reading was timed $2 \mathrm{hr}$ after exposure. Seahorse Sensor Cartridges (Agilent 100867-100) were hydrated for 618 hours at $37^{\circ} \mathrm{C}$ in $1 \mathrm{~mL}$ of the supplied calibrant. Stock solutions of stress test reagents were prepared by dissolving in DMSO, diluting to 10x desired final concentrations with glucose/pyruvate/Glutamax supplemented media, before adding to the appropriate sensor ports. The sensor cartridge was calibrated in a Seahorse XF24 Analyzer, cell plates installed, and OCR measured for $30 \mathrm{~min}$ at baseline, and in response to 2 $\mu \mathrm{M}$ oligomycin (New England Biolabs 9996L), 0.5 MM FCCP (Sigma C2920), and 0.5 $\mu \mathrm{M}$ rotenone/antimycin-A (Sigma R8875 and A8674 respectively). Triplicate technical replicates on each plate were averaged to produce final OCR datapoints, and parameters of mitochondrial function calculated according to the user guide.

\section{Prevention of OxPC induced dysfunction}

ROS formation was used as an initial parameter to determine whether dysfunction induced by OxPC could be prevented. Calu-3 were pre-incubated for 2 hours with vehicle control (0.1\% DMSO), inhibitors of ROS [Nacetyl-L-cysteine (NAC), Sigma-Aldrich A7250], or blockers of receptors associated with OxPC activity including platelet activating factor receptor (WEB-2086, Tocris 2339), prostaglandin EP2 receptor (PF-04418948, Tocris 4814), CD36 [sulfosuccinimidyl oleate (SSO), Cayman Chemical 11211] and toll like receptors 2 and 4 [sparstolonin B (SsnB), Sigma-Aldrich SML1767]. Cells were then loaded with DCF and co-incubated with inhibitors, OxPC (160 $\mu \mathrm{g} / \mathrm{mL})$ and vehicle control (0.1\% DMSO) for a further 2 hours before measuring fluorescence. Subsequently, Calu-3 were treated concurrently with OxPC (80 or $160 \mu \mathrm{g} / \mathrm{mL}$ ) and NAC (0.1 to 10 $\mathrm{mM}$ ) before being subjected to TEER, scratch/proliferation and lipid peroxidation assays. 
bioRxiv preprint doi: https://doi.org/10.1101/823666; this version posted October 26, 2020. The copyright holder for this preprint (which was not certified by peer review) is the author/funder, who has granted bioRxiv a license to display the preprint in perpetuity. It is made available under Oxidized phosphatidylcholines impair epithelial barrier

\section{Data Analysis and Statistics}

All numerical data are presented as mean \pm standard error. Each ' $n$ ' value represents a fully independent experiment created from a separate flask of stock cells. Statistical tests were performed with the GraphPad Prism 6.07 software package, with $p<0.05$ considered statistically significant. Matched samples 1-way ANOVA was used for all OxPC experiments where data was collected at a single time-point, with Dunnett post-tests calculated against control or OxPC $160 \mu \mathrm{g} / \mathrm{mL}$ conditions as appropriate. In TEER recovery experiments, all pairwise Bonferroni post-tests were calculated. For time-course experiments, independent samples 2-way ANOVA (factors: OxPC, time) was performed, with Dunnett post-tests calculated against the untreated control condition. Paired t-test was used for all HDM experiments.

\section{RESULTS}

\section{OxPC induce cell stress and loss of viability in airway epithelial cells}

OxPC treatment resulted in dose-dependent LDH release, indicating cell stress in each cell type tested (Fig 1A). However, the magnitude of the effect was variable across epithelial cell lines with strong responses at low doses in BEAS-2B $(p<0.0001)$, moderate responses in Calu-3 $(p<0.0001)$, and weak responses in $\mathrm{nHBE}$ $(p<0.0001)$ and ALI-nHBE ( $p=0.0257)$. Very high levels of LDH release were associated with loss of viability in BEAS-2B (Fig 1B; $p<0.0001)$ and Calu-3 ( $p<0.0001)$ cells. No loss of viability was detected in nHBE $(p=0.2204)$. Statistical significance was achieved in ALI-nHBE ( $p=0.0438)$, however the magnitude of any effect was small relative to the other cell types, with no obvious dose-dependence and no significant differences relative to control in post-tests. The non-oxidizable negative control PSPC caused no quantitative or qualitative changes in this experiment, or in any subsequent experiment.

\section{OxPC reversibly impair epithelial barrier function and barrier recovery after a wound}

In Calu-3 cells, OxPC exposure at 80 and $160 \mu \mathrm{g} / \mathrm{mL}$ resulted in significant barrier impairment, as measured by both paracellular permeability (Fig 2A; $p<0.0001$ ) and TEER assays (Fig 2B; OxPC $p<0.0001$ ). Large voids in the monolayer representing cell loss were evident after $24 \mathrm{hr}$ in $160 \mu \mathrm{g} / \mathrm{mL}$ OxPC but no cell loss was apparent at $80 \mu \mathrm{g} / \mathrm{mL}$ even after 72 hours, consistent with cell stress and viability assays. The $40 \mu \mathrm{g} / \mathrm{mL}$ dose demonstrated enhanced barrier function by TEER at 24 hours, but this effect was not significant from 48 hours onwards. For ALI-nHBE, OxPC treatment did not cause any difference in permeability (Fig 2C; $p=0.5510$ ), but resulted in significant impairment of TEER (Fig 2D; OxPC $p=0.0007$ ), with strong dose-dependent dysfunction at seven days. 
bioRxiv preprint doi: https://doi.org/10.1101/823666; this version posted October 26, 2020. The copyright holder for this preprint (which was not certified by peer review) is the author/funder, who has granted bioRxiv a license to display the preprint in perpetuity. It is made available under Oxidized phosphatidylcholines impair epithelial barrier

Combining OxPC with a physical scratch revealed that the simultaneous 'two hits' could cause additional barrier dysfunction in Calu-3 cells (Fig 3A; OxPC $p<0.0001$ ). TEER was used to assess wound healing, as it collectively represents the migration, proliferation and junction formation essential to re-establish barrier function. Consistent with unscratched cultures, the 80 and $160 \mu \mathrm{g} / \mathrm{mL}$ groups displayed a failure of wound healing after 24 hours. Surprisingly, combining $\mathrm{OxPC}$ at $40 \mu \mathrm{g} / \mathrm{mL}$ with a scratch resulted in a significant delay in wound healing at 24-48 hours, in stark contrast to the barrier enhancement seen with OxPC treatment alone. To determine whether the effects of OxPC on barrier function after a wound are reversible, scratched Calu-3 were exposed to OxPC for 24 or 72 hours, before the OxPC were washed off, and TEER re-measured after 24 hours. Only OxPC $80 \mu \mathrm{g} / \mathrm{mL}$ treated cells could partially recover barrier function (Fig 3B; $\mathrm{p}=0.0079$ ) and the recovery was more complete with shorter pre-exposure times.

In ALI-nHBE, OxPC at $160 \mu \mathrm{g} / \mathrm{mL}$ caused a modest but highly significant impairment of wound healing at 48 hours, with dose-dependent dysfunction persisting until 7 days (Fig 3C; OxPC $p<0.0001$ ).

\section{OxPC reversibly inhibit DNA synthesis}

Airway epithelial wound healing involves an initial migratory phase followed by increased proliferation at the wounded edge (63), thus we histologically assessed DNA synthesis to better understand the dynamics of barrier recovery in the presence of OxPC (Fig 4). Scratched cultures exhibit increased EdU labelling indicative of DNA synthesis at the leading edge. In contrast, a submaximal $80 \mu \mathrm{g} / \mathrm{mL}$ OxPC dose appropriate for multi-day experiments resulted in a dramatic decrease in DNA synthesis at 24 hours $(p<0.0001)$ DNA synthesis returns to control levels if OxPC are left on the cells for 48 hours but experiences a dramatic rebound if OxPC are washed off the cells, albeit without immediate wound closure. These results are consistent with the barrier function results following both scratch and wash protocols.

\section{OxPC do not affect epithelial phenotype markers}

To determine whether barrier dysfunction was modulated by changes in the epithelial phenotype, the relative mRNA abundance of three key phenotypic markers was measured after OxPC exposure (Fig 5). Neither ecadherin ( $C D H 1, p=0.4295)$ nor vimentin ( $\mathrm{VIM}, \mathrm{p}=0.4362)$ mRNA levels were altered by OxPC, suggesting maintenance of epithelial phenotype and no acquisition of mesenchymal features. Zonula occludens 1 (TJP1) mRNA levels were significantly different across the groups in the ANOVA statistic $(p=0.0069)$, however there was no linear dose-dependence and post-tests revealed no individual group differences. Intriguingly, ubiquitin $C(U B C)$ was dose-dependently regulated by OxPC $(p<0.0001)$. This gene was intended for usage as a housekeeping gene as described previously (58) but is also known to be stress-inducible (19), supporting that OxPC induce cellular stress in epithelial cells. 
bioRxiv preprint doi: https://doi.org/10.1101/823666; this version posted October 26, 2020. The copyright holder for this preprint (which was not certified by peer review) is the author/funder, who has granted bioRxiv a license to display the preprint in perpetuity. It is made available under Oxidized phosphatidylcholines impair epithelial barrier aCC-BY-ND 4.0 International license.

\section{OxPC induce general ROS accumulation}

The established relationship between OxPC and ROS, combined with our collective cell stress data, led us to examine the effect of OxPC on ROS accumulation. OxPC rapidly induced general ROS accumulation in a timeand dose-dependent manner (Fig 6A-B; $\mathrm{p}<0.0001$ ). To put these results in context of known disease-linked modulators, we performed separate experiments exposing cells to a maximal dose of house dust mite (HDM). General ROS accumulation was significantly elevated in response to $\operatorname{HDM}(p=0.0314)$, although the magnitude was markedly lower than a maximal OxPC dose.

To try and ascertain the specific cellular source of ROS, we assessed the accumulation of mitochondrial and cytosolic superoxide. Mitochondrial superoxide was not significantly altered by OxPC treatment (Fig 6C; $p=0.3730$ ). Background fluorescence levels were high for this assay when quantified with a plate reader, but no quantitative or qualitative difference was apparent between control and OxPC conditions when compared with the brightly stained positive control (immunofluorescence microscopy; Fig 6D). Cytosolic superoxide reached statistical significance (Fig 6E; $p=0.0227$ ) however there was no obvious dose-dependence, post-tests were not significant, and the overall magnitude of any OxPC-related response was considerably lower than the corresponding positive control. Moreover, fluorescent imaging shows no qualitative difference between the control and maximal dose of OxPC relative to the much brighter positive control (Fig 6F). These combined results indicate that superoxide accumulation is unlikely to be biologically significant during OxPC exposure.

\section{OxPC induce additional lipid peroxidation}

To determine whether ROS formation could induce ongoing cellular dysfunction, we assessed lipid peroxide generation. Similar to general ROS accumulation, lipid peroxides began accumulating rapidly after OxPC addition, with higher doses surpassing the level of lipid peroxides produced by the positive control cumene$\mathrm{OOH}$ within 60 minutes (Fig 7A). At the 2-hour endpoint, all OxPC doses were significantly higher than control (Fig 8B; $\mathrm{p}<0.0001$ ), with a strong dose-dependency. In separate experiments, HDM was assessed for its ability to induce lipid peroxidation. The effect of HDM approached statistical significance $(p=0.0522)$, but the magnitude of the change was smaller than even the lowest OxPC dose.

To validate these results, lipid peroxidation was assessed by an alternative histological technique that assesses lipid peroxide transfer to proteins (Click-iT Lipid Peroxidation Imaging Kit). OxPC induced a qualitative increase in staining indicating lipid peroxidation and subsequent protein peroxidation, that was diffuse across the cell membrane and cytoplasm. There was no obvious segregation or punctate patterning that would indicate isolation to any specific organelle (Fig 8D). 
bioRxiv preprint doi: https://doi.org/10.1101/823666; this version posted October 26, 2020. The copyright holder for this preprint (which was not certified by peer review) is the author/funder, who has granted bioRxiv a license to display the preprint in perpetuity. It is made available under Oxidized phosphatidylcholines impair epithelial barrier

\section{Mitochondrial function is disrupted by OxPC treatment}

Oxidized phospholipids accumulate in the mitochondria (62), and oxidized lipoproteins can cause mitochondrial membrane hyperpolarisation (23). Moreover, mitochondria are a well-known source of multiple ROS species, and mitochondrial metabolism is required for proliferation. Thus, we determined the effect of OxPC on Calu-3 mitochondrial membrane potential, as well as oxygen consumption during a mitochondrial stress test. Consistent with earlier work, OxPC induced a dose-dependent increase in TMRM staining, indicative of mitochondrial hyperpolarisation (Fig 8A; $p<0.0001$ ). Moreover, OxPC caused profound alterations in oxygen consumption rate (OCR) during the stress test (Fig 8B; OxPC $p<0.0001$ ), with specific dose-dependent reductions in each of basal respiration (Fig $8 C ; p=0.0165)$, ATP-linked respiration $(p<0.0001)$ and maximal respiration $(p=0.0013)$, dose-dependent increases in proton leak $(p=0.0002)$, but no change in nonmitochondrial respiration $(p=0.0952)$.

\section{OxPC receptor blockade does not mitigate OxPC-induced ROS accumulation}

In other cell types, the negative effects of OxPC are associated with specific receptor-mediated pathways (34). To determine whether these pathways are responsible for our results in epithelial cells, Calu-3 were exposed to a maximal $160 \mu \mathrm{g} / \mathrm{mL}$ OxPC dose in the presence of putative OxPC receptor blockers (Fig 9A). For each of the PAFR (WEB-2086; $p=0.1179$ ), EP2 (PF-04418948; $p=0.5317)$, CD36 (SSO; $p=0.7256$ ) and TLR2/4 receptors (SsnB; $\mathrm{p}=0.1664$ ), blocking agents did not inhibit general ROS accumulation. In contrast, the antioxidant NAC inhibited ROS in a dose-dependent manner, completely reversing ROS accumulation at a supraphysiological $10 \mathrm{mM}$ dose $(p=0.0004)$.

\section{OxPC induced dysfunction can be partially prevented by NAC}

To determine the capacity for NAC to prevent OxPC induced dysfunction, Calu-3 were treated concurrently with OxPC and NAC and re-assessed for barrier function, DNA synthesis after a wound, and lipid peroxidation. At a physiological $1 \mathrm{mM}$ dose, NAC was able to delay the barrier dysfunction induced by $80 \mu \mathrm{g} / \mathrm{mL}$ OxPC for up to 48 hours (Fig 9B; OxPC $p<0.0001$ ). However, NAC could not abrogate the dysfunction induced by a maximal $160 \mu \mathrm{g} / \mathrm{mL}$ OxPC dose (OxPC $\mathrm{p}<0.0001$ ). Consistent with these data, NAC prevented the reduction in DNA synthesis after a wound in the presence of $80 \mu \mathrm{g} / \mathrm{mL}$ OxPC (Fig 9D; $\mathrm{p}=0.0054$ ), but could not completely inhibit lipid peroxidation to $160 \mu \mathrm{g} / \mathrm{mL}$ OxPC (Fig 9E; $\mathrm{p}=0.0001$ ). 
bioRxiv preprint doi: https://doi.org/10.1101/823666; this version posted October 26, 2020. The copyright holder for this preprint (which was not certified by peer review) is the author/funder, who has granted bioRxiv a license to display the preprint in perpetuity. It is made available under Oxidized phosphatidylcholines impair epithelial barrier

\section{DISCUSSION}

\section{Epithelial dysfunction and physiological relevance}

The airway epithelial barrier is the gateway to the lung and dysfunction of this barrier at a cellular level is associated with both asthma pathogenesis (29) and asthma severity (38). For this reason, we sought to explore the ability of OxPC to induce epithelial barrier dysfunction in the context of asthma. Our results indicate that OxPC can disrupt normal airway epithelial cell function and promote pathologic features similar to those seen in the airways of people with asthma. This includes a loss of barrier integrity (25), impaired capacity to reestablish barrier function after a wound (52), and further production of reactive oxygen species (14). This wide range of cellular dysfunction was accompanied by disruption of mitochondrial metabolism. Critically, each deleterious response was observed at doses below the threshold for detecting cell stress and loss of viability, i.e., $80 \mu \mathrm{g} / \mathrm{mL}$, which is comparable to the level of OxPC seen in the airways of mouse models of asthma (31).

Wounding the epithelial layer increased the barrier-disrupting potency of OxPC, making OxPC effective at lower doses (Calu-3) and at earlier timepoints (ALI-nHBE). This suggests that OxPC could be important in potentiating the negative effects of allergenic insults or other stressors in diseased airways. In this regard, exposing epithelial cells to HDM resulted in an increase in ROS that was considerably smaller than the level induced by low doses of OxPC. Additionally, OxPC exposure could stimulate further production of lipid peroxides indicating the potential for a self-propagating cycle that starts with allergen exposure. Interestingly, the negative effects of OxPC could be reversed by simply washing the cells suggesting they do not cause permanent cell damage or irrecoverable activation of cell death pathways, and intracellular accumulation is not required. Instead, dysfunction seems to be dependent only on overall OxPC exposure. Therefore, OxPC are potentially important molecules in the pathogenesis of asthma and interventions aimed at limiting their production or promoting their removal from the airway milieu could be novel therapeutic options for this disease.

OxPC have been identified as a bioactive lipid molecule relevant to many chronic human diseases. In atherosclerosis, blocking the action of OxPC with the antibody E06 in mice reduced the amount of atherosclerosis and aortic valve calcifications (44). Following renal ischemia reperfusion injury in rats, there was a significant elevation in 55 OxPC species which correlated with the severity of the injury (50). Recently, members of our team have identified OxPC in the airways of mice and humans following allergen challenge and these were shown to be correlated with methacholine responsiveness (41). In airway smooth muscle cells, OxPC promote an inflammatory phenotype, characterized by secretion of IL-6, IL-8, GM-CSF, the production of eicosanoids, and were controlled by signaling events through protein kinase $\mathrm{C}$. We were unable to detect similar OxPC-linked inflammatory mediator secretion from Calu-3 cells (data not shown), suggesting that OxPC contribute to disease pathology through more than one distinct mechanism. Thus, developing treatments that 
bioRxiv preprint doi: https://doi.org/10.1101/823666; this version posted October 26, 2020. The copyright holder for this preprint (which was not certified by peer review) is the author/funder, who has granted bioRxiv a license to display the preprint in perpetuity. It is made available under Oxidized phosphatidylcholines impair epithelial barrier

target the actions of OxPCs in the airways could offer us a better way to ameliorate the effects of oxidative stress in asthma, therefore augmenting current treatment regimes.

\section{Mechanisms of oxidative stress and lipid peroxidation}

OxPC have been linked to signaling events involving PAFR, EP2, CD36 and TLR2/4 (34,57). We were unable to show that any of these receptors were involved in mediating accumulation of ROS in response to OxPC in this study; only pre-incubation with the antioxidant NAC was able to reduce the cellular accumulation of ROS. Subsequently, we showed that NAC co-treatment reduced lipid peroxidation, increased proliferation capacity after a wound, and delayed barrier dysfunction to a submaximal $80 \mu \mathrm{g} / \mathrm{mL}$ OxPC dose. NAC operates as a cysteine source for the production of glutathione (47) and the glutathione anti-oxidant system is finely tuned for controlling cellular levels of lipid peroxides (60). In children with severe asthma, oxidized glutathione levels are significantly elevated and reduced glutathione levels are significantly repressed (18) indicating an elevated level of oxidative stress. Additionally, single nucleotide polymorphisms (SNPs) associated with increased asthma risk are present in some of the genes for glutathione-s-transferase enzymes, $(32,53)$. Disequilibrium in the glutathione system could thus indicate a diminished ability to detoxify OxPC in the airways and may render people with asthma particularly susceptible to the effects of OxPC. An alternative antioxidant mechanism for NAC involves triggering intracellular sulfane sulfur production which has antioxidant and cytoprotective functions (15). In this regard, treatments that increase endogenous production of sulfane sulfur could be useful in decreasing the antioxidant burden in asthma, specifically related to OxPC.

Yet despite the theoretical benefits of antioxidant treatments for asthma, results from animal and patient studies are mixed. With the exception of particular vitamin E isoforms that may specifically detoxify lipid peroxides $(27,43)$, dietary antioxidant supplementation seems to provide minimal benefit beyond a decrease in exhaled FeNO $(1,42,54,59)$. This may be consistent with our observations that NAC was unable to completely reverse lipid peroxidation and barrier dysfunction at a maximal $160 \mu \mathrm{g} / \mathrm{mL}$ OxPC dose, and that neither mitochondrial nor cytosolic superoxide are credible sources for the large magnitude of dysfunction we observed. This raises the possibility that the primary pathology induced by OxPC is specifically associated with lipid metabolism. Xenobiotic metabolism involving cytochrome P450, lipoxygenase and cyclooxygenase are well known to produce lipid peroxide by-products and these reactions can be self-propagating in the presence of oxygen (2). However, our demonstration of mitochondrial dysfunction after OxPC exposure, combined with previous observations that cardiolipin oxidation leads to lipid peroxidation in endothelial cells, suggests direct interference with mitochondrial lipid metabolism $(6,39)$. In this case, ROS and lipid peroxides would be produced that were detectable by our assays, but without necessarily producing a detectable superoxide intermediate. Metabolomic analysis of OxPC affected cells will be required to precisely determine which lipid 
bioRxiv preprint doi: https://doi.org/10.1101/823666; this version posted October 26, 2020. The copyright holder for this preprint (which was not certified by peer review) is the author/funder, who has granted bioRxiv a license to display the preprint in perpetuity. It is made available under Oxidized phosphatidylcholines impair epithelial barrier

peroxides are produced, the mitochondrial reactions/enzymes that are responsible, and how this process could be mitigated.

\section{Differential cell responses}

Intriguingly, we found significant differences in the responsiveness of different epithelial cells to OxPC exposure. This may represent a culturing artifact or altered metabolic requirements of undifferentiated epithelial cells and cell lines but may also highlight how OxPC become disease relevant. Airway epithelium from people with asthma exhibits an elevated number of basal cells and a reduction in the number of cells expressing E-cadherin (24) suggesting a more immature phenotype. In this regard, airway epithelium from asthma may be more susceptible to the effects of OxPC due to its relatively undifferentiated state, although it is important to note that the cells used in this study are not sourced from asthmatic patients. Alternatively, commercial supplements for culturing primary epithelial cells in ALI contain hydrocortisone which has been shown to inhibit the inflammatory response of cultured epithelial cells (17) and support mucociliary transport (64). Importantly, glucocorticoids have been shown to increase the activity of antioxidant enzymes in asthma (11). We did not remove hydrocortisone from the media prior to experimentation which may have conferred some protection and reduced the effect sizes seen in primary cells. Finally, OxPC had a significant impact on DNA synthesis in our experiments suggesting that they may directly inhibit proliferation. Primary cells are relatively quiescent compared with the cell lines used in this study perhaps indicating that proliferating cells, or those that have an associated high metabolic requirement, are particularly susceptible to OxPC exposure. It will therefore be important to study how prolonged OxPC treatment alters the growth and differentiation trajectory of primary epithelial cells, to determine the effect on mucociliary phenotype and barrier function.

\section{Summary}

We have demonstrated that OxPC induce dose-dependent cellular dysfunction that may potentiate other stressors to manifest as impaired epithelial barrier function in diseased airways. Future work will need to ascertain whether the cellular dysfunction we have observed is a product of the combination and total quantity of OxPC applied or can be attributable to a single OxPC species operating through a specific mechanism. Understanding the role of individual OxPC in causing epithelial cell dysfunction will help us to identify potential treatment options that protect the cell or 'mop-up' OxPC in a more specific manner than NAC, and more completely prevent lipid peroxide accumulation and barrier dysfunction. It will also be important to ascertain whether cells from asthmatic patients might be more susceptible to OxPC because of deficiencies in antioxidant systems or immaturity of epithelial phenotype. Finally, by using mice that express the anti-OxPC antibody (E06), and determining whether OxPC can augment the pathology associated with HDM exposure, it will be possible to discover whether OxPC are sufficient and necessary for the pathogenesis of airway disease. 
bioRxiv preprint doi: https://doi.org/10.1101/823666; this version posted October 26, 2020. The copyright holder for this preprint (which was not certified by peer review) is the author/funder, who has granted bioRxiv a license to display the preprint in perpetuity. It is made available under Oxidized phosphatidylcholines impair epithelial barrier aCC-BY-ND 4.0 International license.

\section{ACKNOWLEDGEMENTS}

Adrian West is supported by NSERC Discovery Grant \# RGPIN-2014-06412 and Research Manitoba New Investigator Operating Grant \# 1653. Chris Pascoe is supported by Research Manitoba Postdoctoral Fellowship \# 1772, a Canadian Respiratory Research Network Fellowship and the Canadian Institutes of Health Research Banting Postdoctoral Fellowship. Neilloy Roy is supported by Research Manitoba and CHRIM Graduate Studentship \# 1329. Jignesh Vaghasiya is supported by Research Manitoba and CHRIM Graduate Studentship \# \#3735 and \#4196. Andrew Halayko is supported by the Canada Research Chairs Program, and portions of this work were supported by funding from the CIHR Canadian Respiratory Research Network and the Children's Hospital Research Institute of Manitoba. The authors would like to thank Gerald Stelmack for assistance with Beas-2B cell culture.

\section{AUTHOR CONTRIBUTIONS}

Chris Pascoe co-wrote the manuscript, designed experiments, generated OxPC, and performed cell culture, ROS/superoxide assays, lipid peroxidation assays, and mitochondrial function assays.

Neilloy Roy performed paracellular permeability assays.

Emily Turner-Brannen performed cell culture, cell stress/viability assays, TEER measurements, mRNA abundance analysis, proliferation assays, and mitochondrial function assays.

Alexander Schultz performed HDM ROS and HDM lipid peroxide assays. Jignesh Vaghasiya generated OxPC.

Amir Ravandi conceived methods to generate OxPC, and performed mass spectrometric assessment of the OxPC mixture.

Andrew Halayko helped conceive the study and in vitro protocols for using OxPC, edited the manuscript, generated OxPC, and supplied OxPC receptor inhibitors.

Adrian West conceived the study, co-wrote the manuscript, designed/supervized all aspects of experimentation, and performed data/statistical analysis, cell culture and TEER measurements. 
bioRxiv preprint doi: https://doi.org/10.1101/823666; this version posted October 26,2020 . The copyright holder for this preprint (which was not certified by peer review) is the author/funder, who has granted bioRxiv a license to display the preprint in perpetuity. It is made available under Oxidized phosphatidylcholines impair epithelial barrier

Pascoe et al.

TABLE 1.

Primers used for mRNA abundance analysis by RT-qPCR. Primers were selected using Primer-BLAST [http://www.ncbi.nlm.nih.gov/tools/primer-blast/ (61)] to span exon-exon junctions to prevent amplification of genomic DNA, with primer specificity continually assessed by melting curve analysis.

\begin{tabular}{|c|c|c|c|c|}
\hline $\begin{array}{l}\text { Common name (code), } \\
\text { function }\end{array}$ & Forward primer $\left(5^{\prime}-3^{\prime}\right)$ & Reverse Primer $\left(5^{\prime}-3^{\prime}\right)$ & $\begin{array}{l}\text { Accession no. } \\
\text { (amplicon } \\
\text { location) }\end{array}$ & $\begin{array}{c}\text { Efficiency } \\
\text { (stability; M) }\end{array}$ \\
\hline $\begin{array}{c}\text { Glyceraldehyde-3- } \\
\text { phosphate dehydrogenase } \\
\text { (GAPDH), housekeeping }\end{array}$ & CTGACTTCAACAGCGACACC & CGTTGTCATACCAGGAAATGAG & $\begin{array}{c}\text { NM_002046.5 } \\
(1039-1137)\end{array}$ & $\begin{array}{c}1.955 \\
(0.216)\end{array}$ \\
\hline $\begin{array}{l}\text { 14-3-3 protein zeta/delta } \\
\text { (YWHAZ), housekeeping }\end{array}$ & TCCCCAGAGAAAGCCTGCTC & ATCCGATGTCCACAATGTCAAG & $\begin{array}{c}\text { NM_003406.3 } \\
(688-831)\end{array}$ & $\begin{array}{c}1.962 \\
(0.216)\end{array}$ \\
\hline $\begin{array}{c}\text { Ubiquitin C (UBC), } \\
\text { housekeeping and stress } \\
\text { inducible }\end{array}$ & TGGCACAGCTAGTTCCGTC & CACGAAGATCTGCATTGTCAAGTG & $\begin{array}{c}\text { NM_021009.6 } \\
(382-450)\end{array}$ & $\begin{array}{c}2.011 \\
(0.718 ; \text { not } \\
\text { stable })\end{array}$ \\
\hline $\begin{array}{c}\text { e-cadherin (CDH1), barrier } \\
\text { marker }\end{array}$ & GCTGGACCGAGAGAGTTTCC & GCTGTTGTGCTTAACCCCTC & $\begin{array}{c}\text { NM_004360.3 } \\
(1120-1200)\end{array}$ & 2.039 \\
\hline $\begin{array}{c}\text { Zonula occludens-1 (TJP1), } \\
\text { barrier marker }\end{array}$ & GAAATCGCACAGTTTGGCAC & GCTGAAGGACTCACAGGAATAG & $\begin{array}{c}\text { NM_003257.4 } \\
(5200-5334)\end{array}$ & 2.003 \\
\hline $\begin{array}{c}\text { Vimentin (VIM), } \\
\text { mesenchymal marker }\end{array}$ & ATCCAAGTTTGCTGACCTCTC & TCAGTGGACTCCTGCTTTGC & $\begin{array}{l}\text { NM_003380.3 } \\
(1289-1366)\end{array}$ & 1.942 \\
\hline
\end{tabular}


bioRxiv preprint doi: https://doi.org/10.1101/823666; this version posted October 26, 2020. The copyright holder for this preprint (which was not certified by peer review) is the author/funder, who has granted bioRxiv a license to display the preprint in perpetuity. It is made available under Oxidized phosphatidylcholines impair epithelial barrier

FIGURES
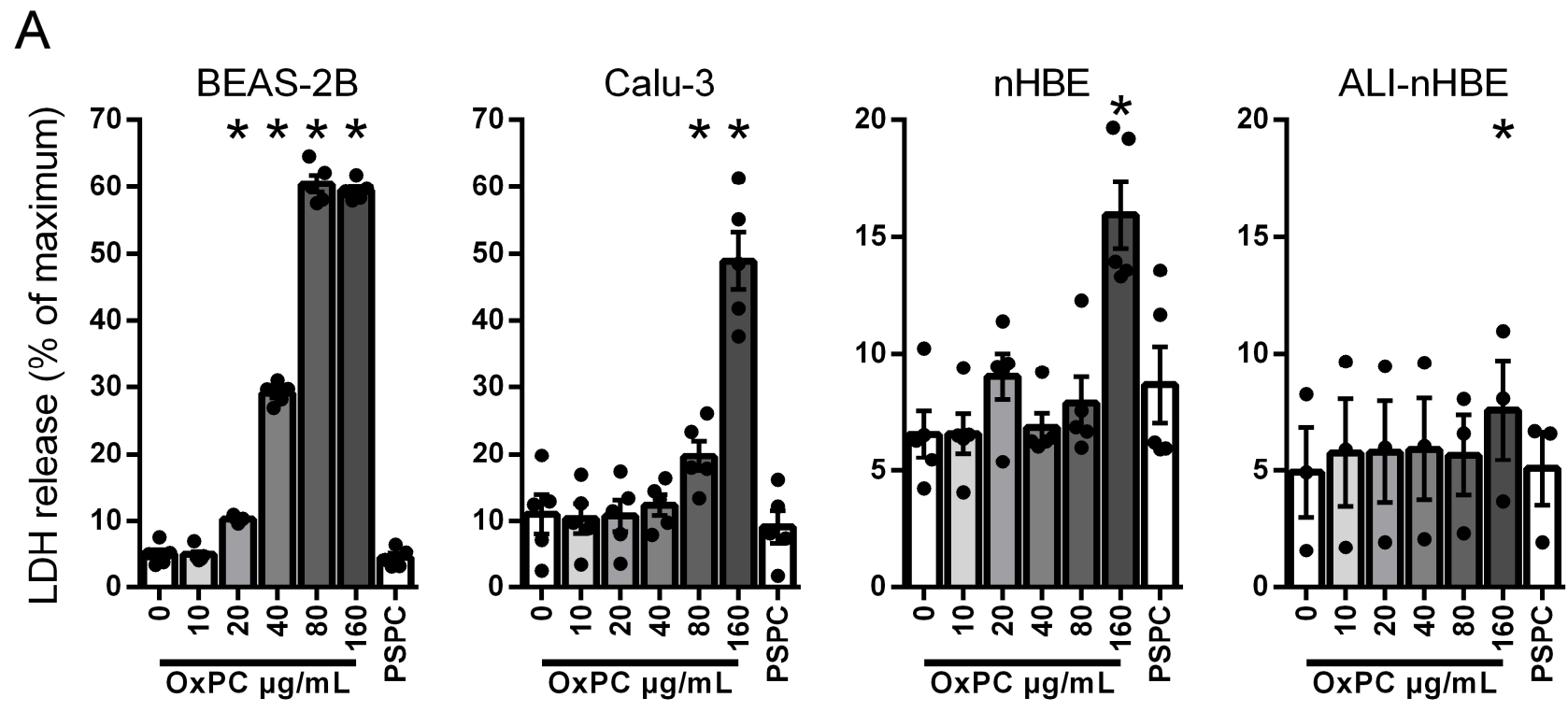

B
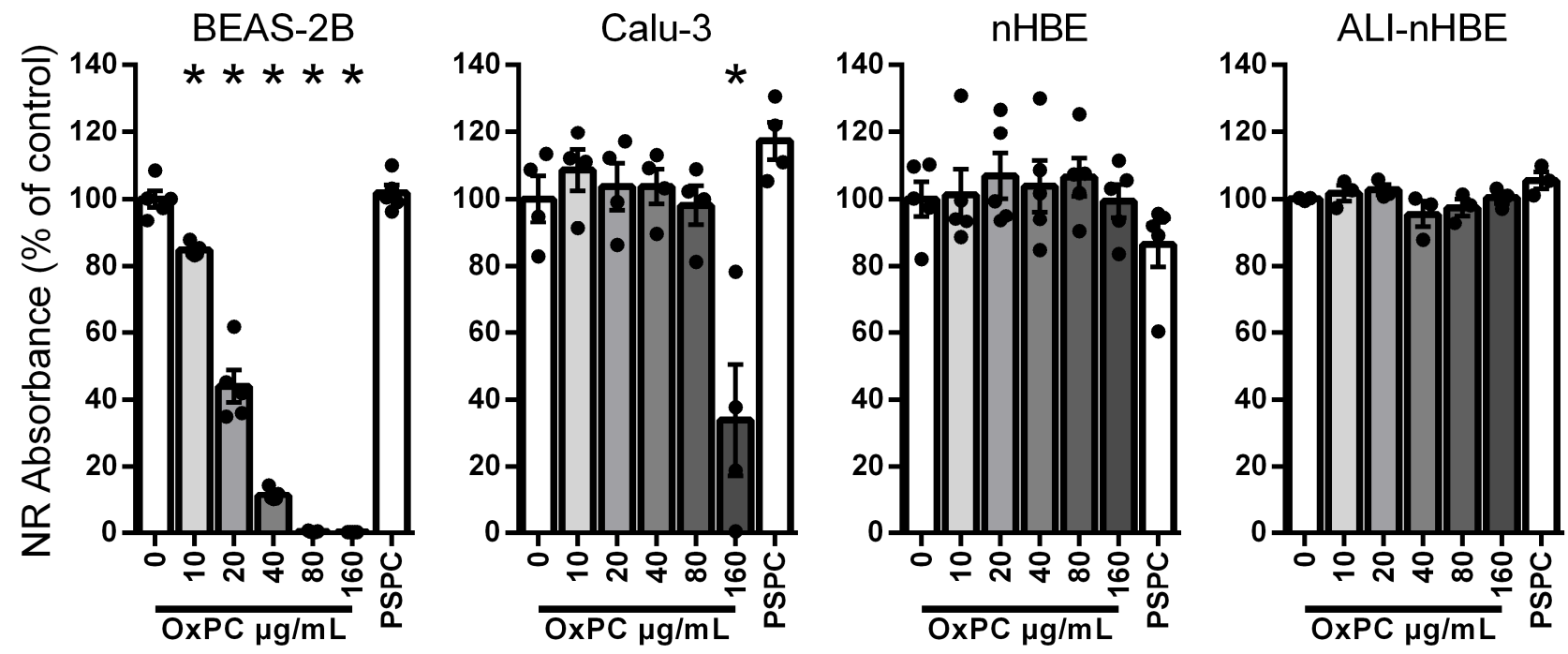

Figure 1.

OxPC induces cell stress ( $\mathrm{A}$; increased LDH release) and loss of cell viability ( $\mathrm{B}$; reduced NR absorbance) in a dose-dependent and cell-specific manner. BEAS-2B were particularly sensitive experiencing almost complete cell death at $40 \mu \mathrm{g} / \mathrm{mL}$ OxPC (stress $p<0.0001$, viability $p<0.0001, n=5$ ). Calu-3 were moderately sensitive (stress $p<0.0001$, viability $p<0.0001, n \geq 4$ ) with cytotoxicity only apparent at $160 \mu \mathrm{g} / \mathrm{mL} 0 x P C$, whereas $n H B E$ (stress $p<0.0001$, viability $p=0.2204, n=5$ ) and ALI-nHBE (stress $p=0.0257$, viability $p=0.0438, n=3$ ) were relatively robust. * represents a significant difference from the $0 \mu \mathrm{g} / \mathrm{mL}$ OxPC control condition. 
bioRxiv preprint doi: https://doi.org/10.1101/823666; this version posted October 26, 2020. The copyright holder for this preprint (which was not certified by peer review) is the author/funder, who has granted bioRxiv a license to display the preprint in perpetuity. It is made available under Oxidized phosphatidylcholines impair epithelial barrier

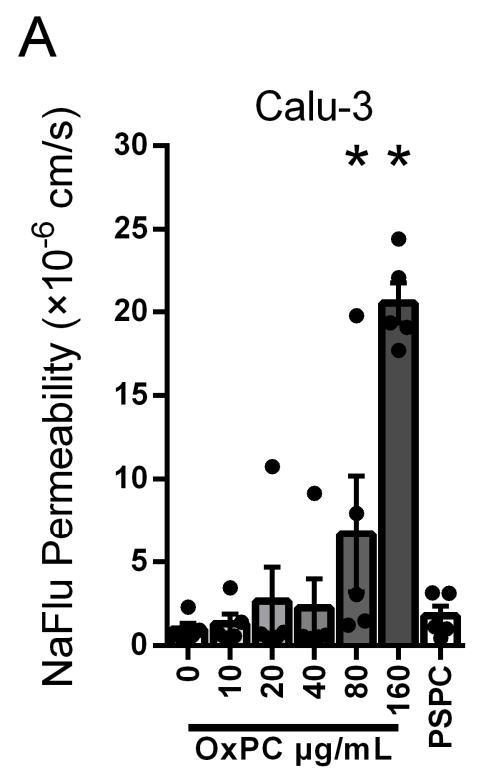

B

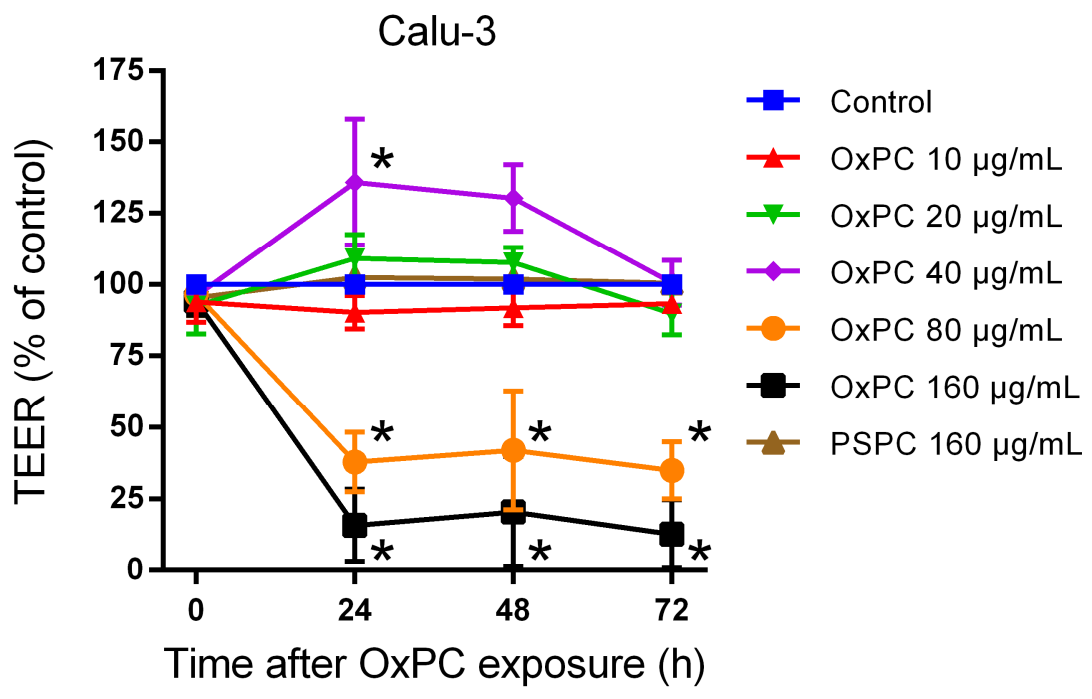

C
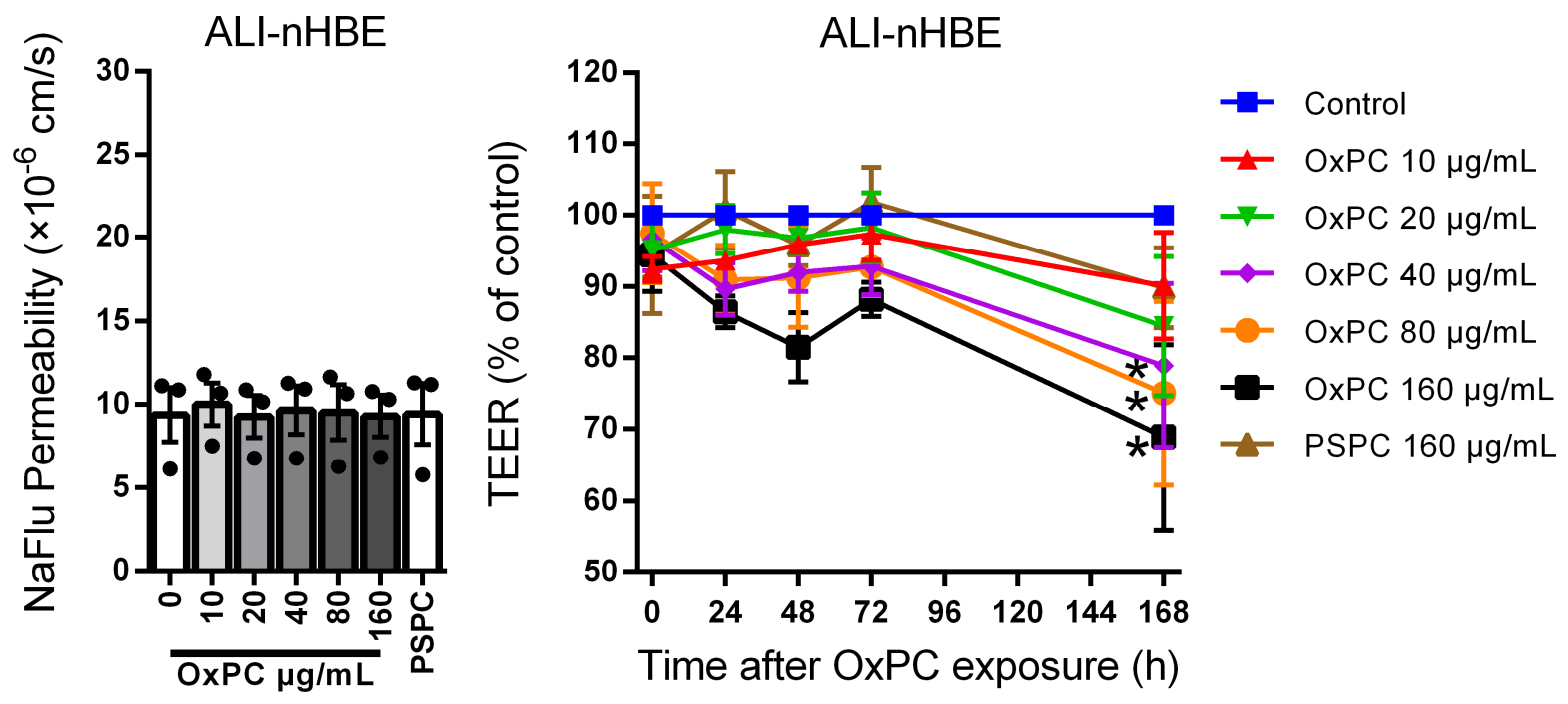

Figure 2.

Under static conditions, barrier function was impaired by OxPC in a dose-dependent and cell-specific manner. Calu-3 exhibited dysfunction in both paracellular permeability $(A ; p<0.0001, n=5)$ and TEER $(B$; interaction $p<0.0001$, time $p=0.0030$, OxPC $p<0.0001, n=4)$ at $80-160 \mu \mathrm{g} / \mathrm{mL}$. The effect of OxPC on ALI-nHBE is not significant for permeability ( $C ; p=0.5510, n=3$ ) but is significant for TEER ( $D$; interaction $p=0.9909$, time $p=0.0007, \operatorname{OxPC} p=0.0232, n=3$ ), with strong dose dependent dysfunction apparent at 7 days. * represents difference from the $0 \mu \mathrm{g} / \mathrm{mL} O x P C$ control condition. 
bioRxiv preprint doi: https://doi.org/10.1101/823666; this version posted October 26, 2020. The copyright holder for this preprint (which was not certified by peer review) is the author/funder, who has granted bioRxiv a license to display the preprint in perpetuity. It is made available under Oxidized phosphatidylcholines impair epithelial barrier

Pascoe et al.
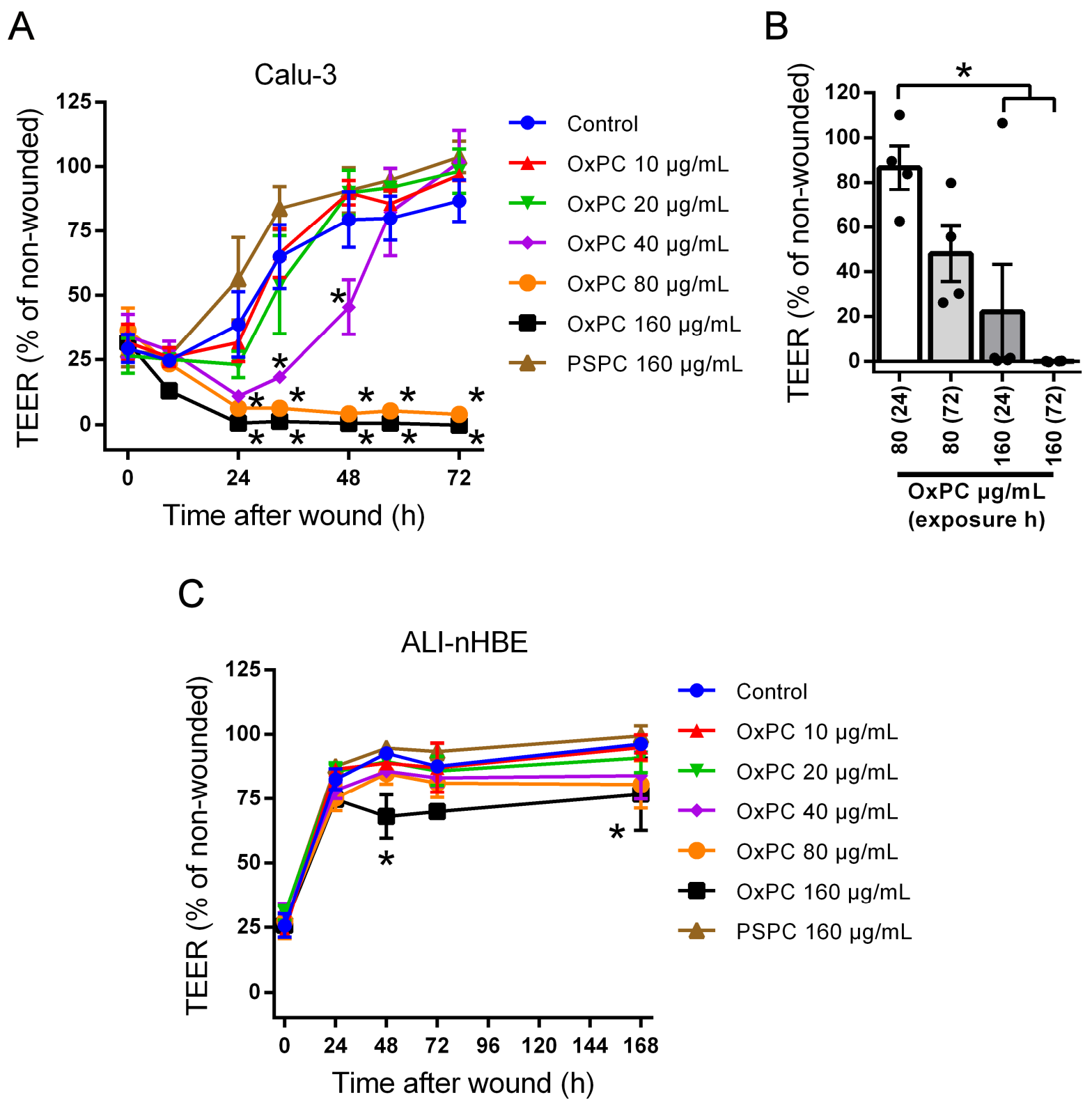

Figure 3.

OxPC treatment potentiates barrier dysfunction after a wound. In Calu-3 cells, OxPC at $40 \mu \mathrm{g} / \mathrm{mL}$ significantly delayed recovery of barrier function (contrast with the lack of defect at $40 \mu \mathrm{g} / \mathrm{mL}$ in Fig 2B) with ongoing dysfunction evident at 80-160 $\mu \mathrm{g} / \mathrm{mL}$ ( $A$; interaction $p<0.0001$, time $p<0.0001,0 x P C p<0.0001, n \geq 4$ ). However, barrier function could partially recover in the $80 \mu \mathrm{g} / \mathrm{mL}$ condition if OxPC are rapidly washed off (B; $p=0.0079 n \geq 4$ ). Scratched ALI-nHBE cultures display defective wound healing in the OxPC $160 \mu \mathrm{g} / \mathrm{mL}$ group (C; interaction $p=0.8773$, time $p<0.0001$, OxPC $p<0.0001$ ) that is not evident until later timepoints in static cultures (contrast with the lack of significant defect for $160 \mu \mathrm{g} / \mathrm{mL}$ at $48 \mathrm{hrs}$ in Fig 2D). * represents significant difference from the $0 \mu \mathrm{g} / \mathrm{mL} \mathrm{OxPC}$ control condition (wound healing) or between conditions (washout recovery). 
bioRxiv preprint doi: https://doi.org/10.1101/823666; this version posted October 26,2020 . The copyright holder for this preprint (which was not certified by peer review) is the author/funder, who has granted bioRxiv a license to display the preprint in perpetuity. It is made available under aCC-BY-ND 4.0 International license.

Oxidized phosphatidylcholines impair epithelial barrier

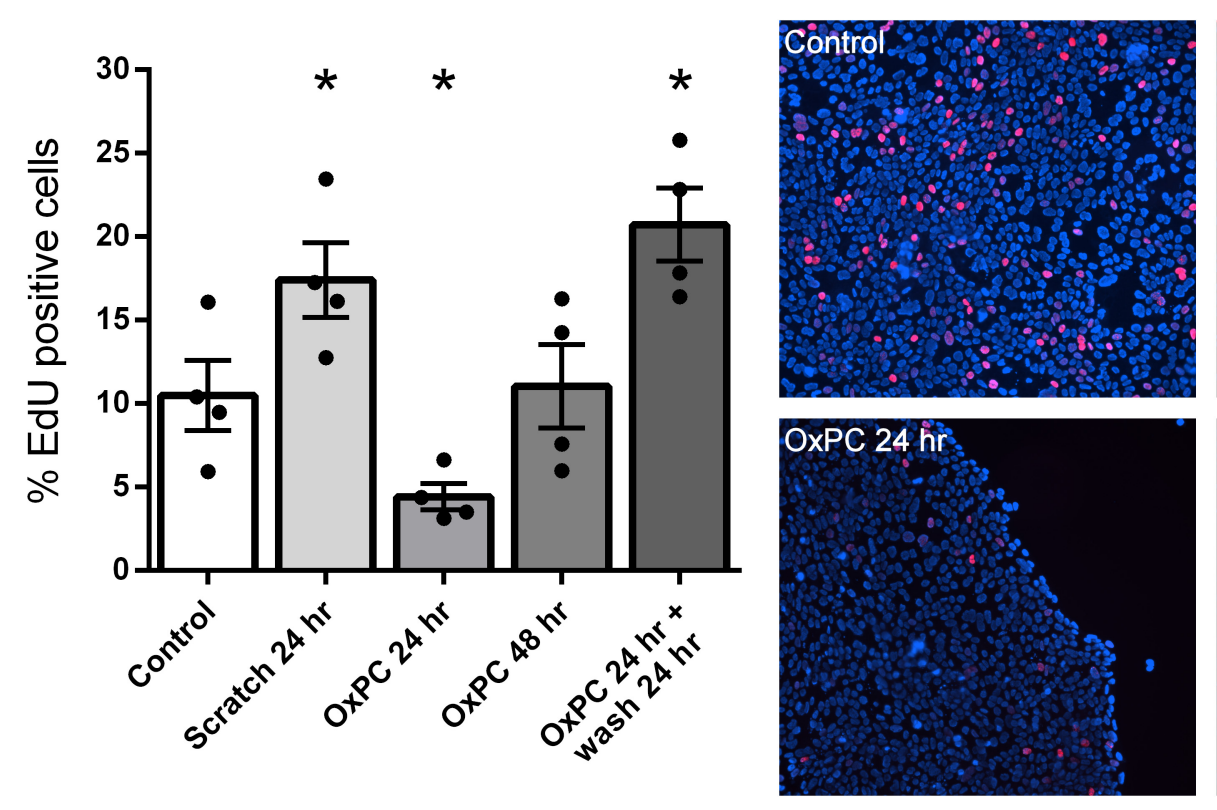

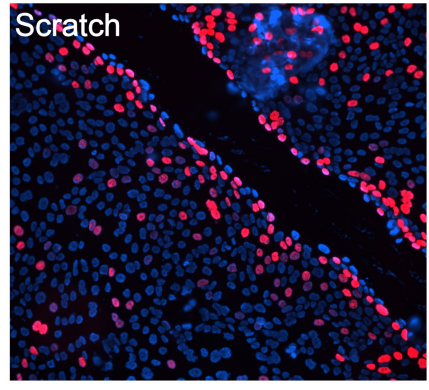

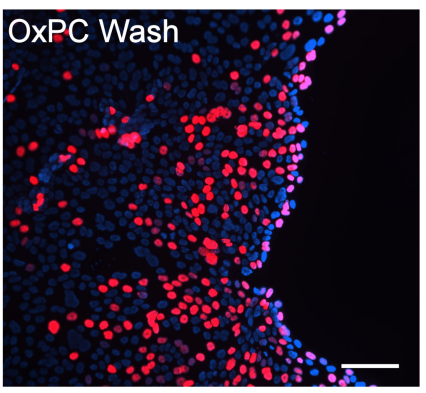

\section{Figure 4.}

DNA synthesis in Calu-3 cells is upregulated on the leading edge after a scratch, but this is significantly inhibited by $80 \mu \mathrm{g} / \mathrm{mL}$ OxPC ( $<<0.0001, \mathrm{n}=4)$. DNA synthesis recovers if OxPC are washed off, but without immediate wound closure. * represents significant difference from the $0 \mu \mathrm{g} / \mathrm{mL}$ OxPC control condition. Scale bar is 100 $\mu \mathrm{m}$. 
bioRxiv preprint doi: https://doi.org/10.1101/823666; this version posted October 26, 2020. The copyright holder for this preprint (which was not certified by peer review) is the author/funder, who has granted bioRxiv a license to display the preprint in perpetuity. It is made available under Oxidized phosphatidylcholines impair epithelial barrier
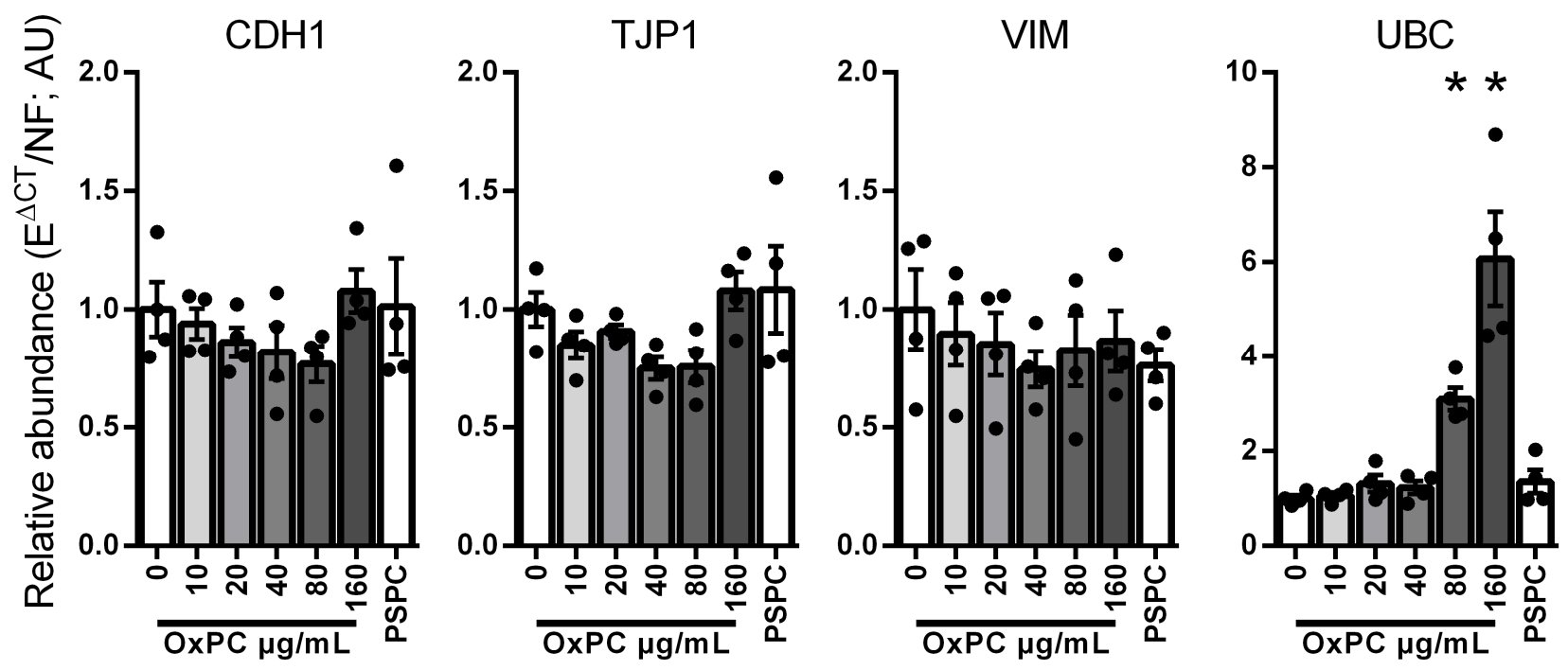

Figure 5.

Markers for epithelial and barrier phenotype are not appreciably regulated by OxPC in Calu-3 cells. The mRNA abundance of $\mathrm{CDH} 1(p=0.4295, n=4)$ and VIM $(p=0.4362, n=4)$ were not significantly altered after OxPC treatment. While statistical significance was detected for TJP1 mRNA levels $(p=0.0069, n=4)$, the small magnitude of the changes and lack of dose-dependency makes it unlikely that modulation of this gene is responsible for the observed barrier dysfunction. In contrast, the stress-inducible gene UBC demonstrated strong dose-dependent regulation by OxPC $(p<0.0001, n=4)$. 
bioRxiv preprint doi: https://doi.org/10.1101/823666; this version posted October 26, 2020. The copyright holder for this preprint (which was not certified by peer review) is the author/funder, who has granted bioRxiv a license to display the preprint in perpetuity. It is made available under Oxidized phosphatidylcholines impair epithelial barrier

Pascoe et al.
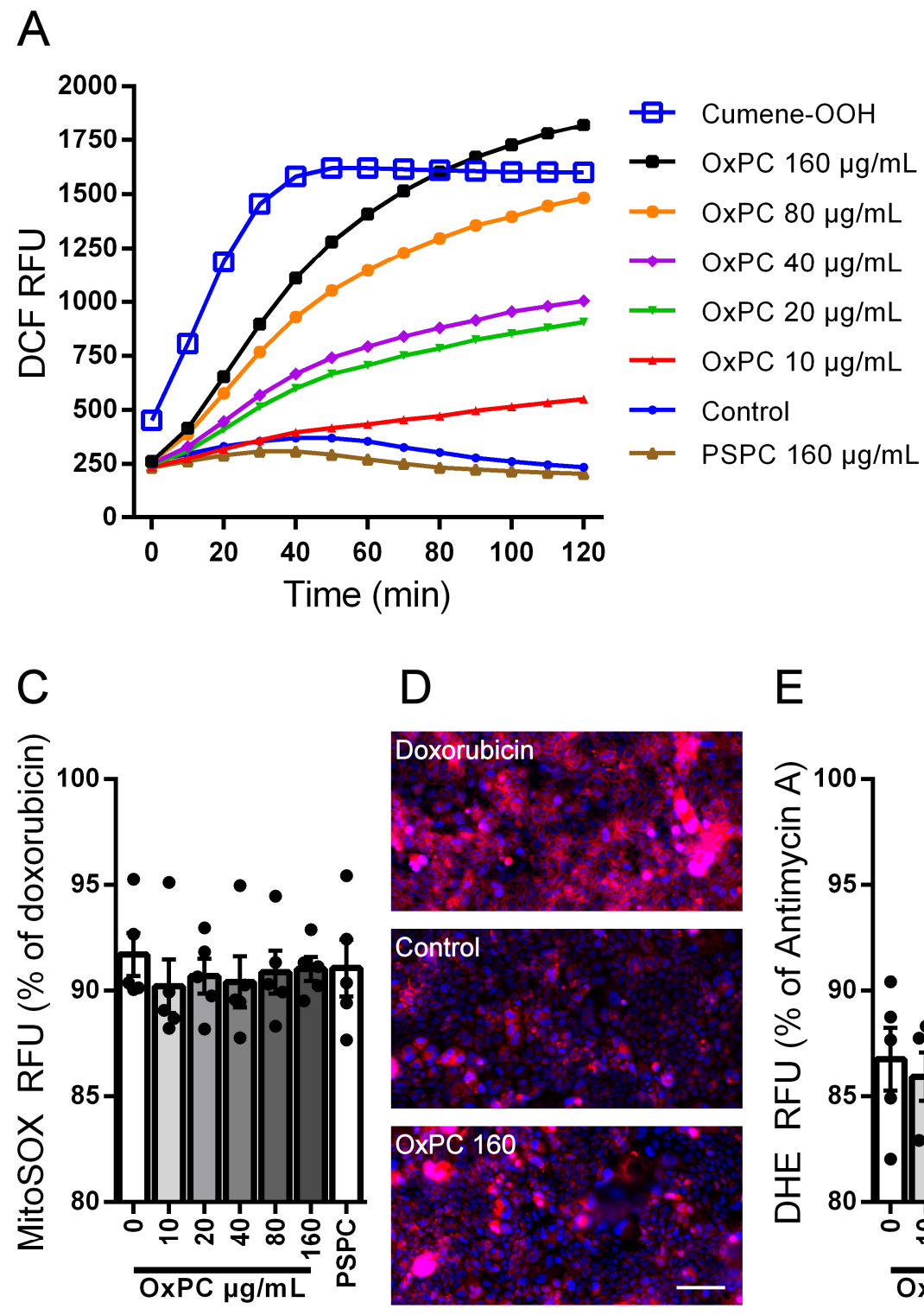

B

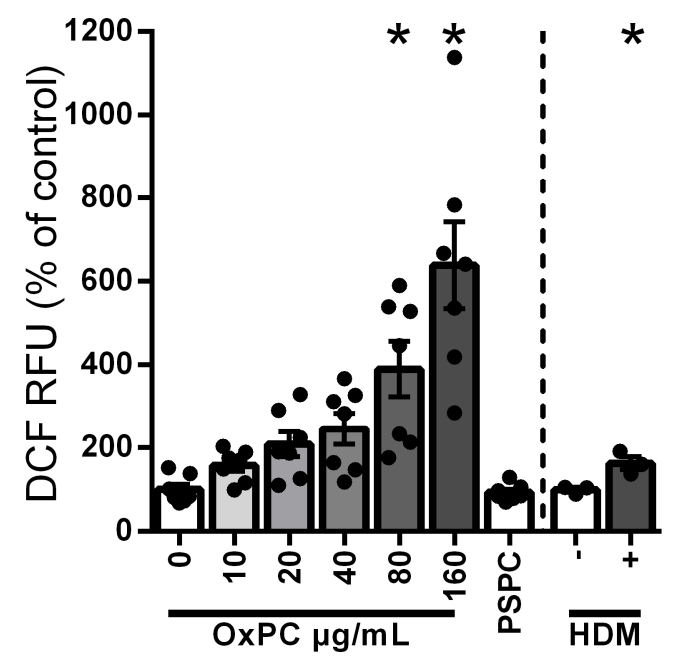

$E$

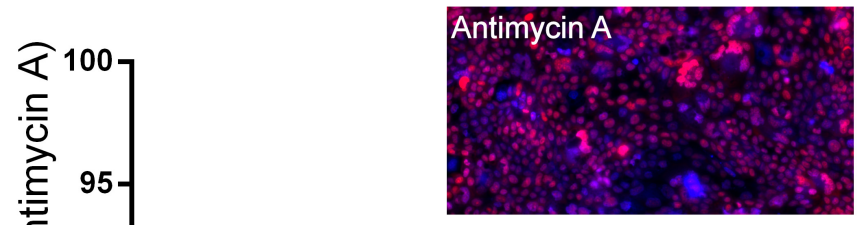

Control

Figure 6.

OxPC induce time- (A) and dose-dependent (B) general ROS accumulation in Calu-3 cells ( $p<0.0001, n=7)$. HDM is also capable of inducing ROS accumulation ( $p=0.0314, n=3)$, but with a much smaller magnitude. Mitochondrial ( $C-D ; p=0.3730, n=5)$ and cytosolic $(E-F ; p=0.0227, n=5)$ superoxide are only marginally influenced by OxPC, with no obvious dose-dependence and significantly lower signal than their respective positive controls. * represents significant difference from the $0 \mu \mathrm{g} / \mathrm{mL}$ OxPC control condition. Scale bar is 100 $\mu \mathrm{m}$. 
bioRxiv preprint doi: https://doi.org/10.1101/823666; this version posted October 26, 2020. The copyright holder for this preprint (which was not certified by peer review) is the author/funder, who has granted bioRxiv a license to display the preprint in perpetuity. It is made available under Oxidized phosphatidylcholines impair epithelial barrier
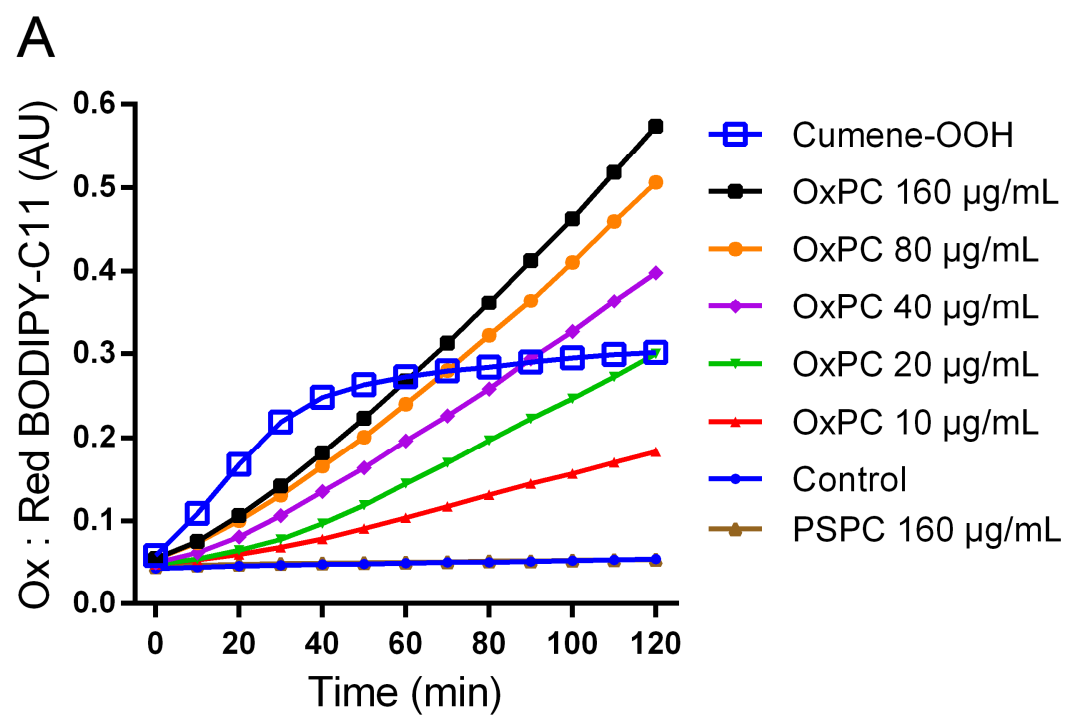

B
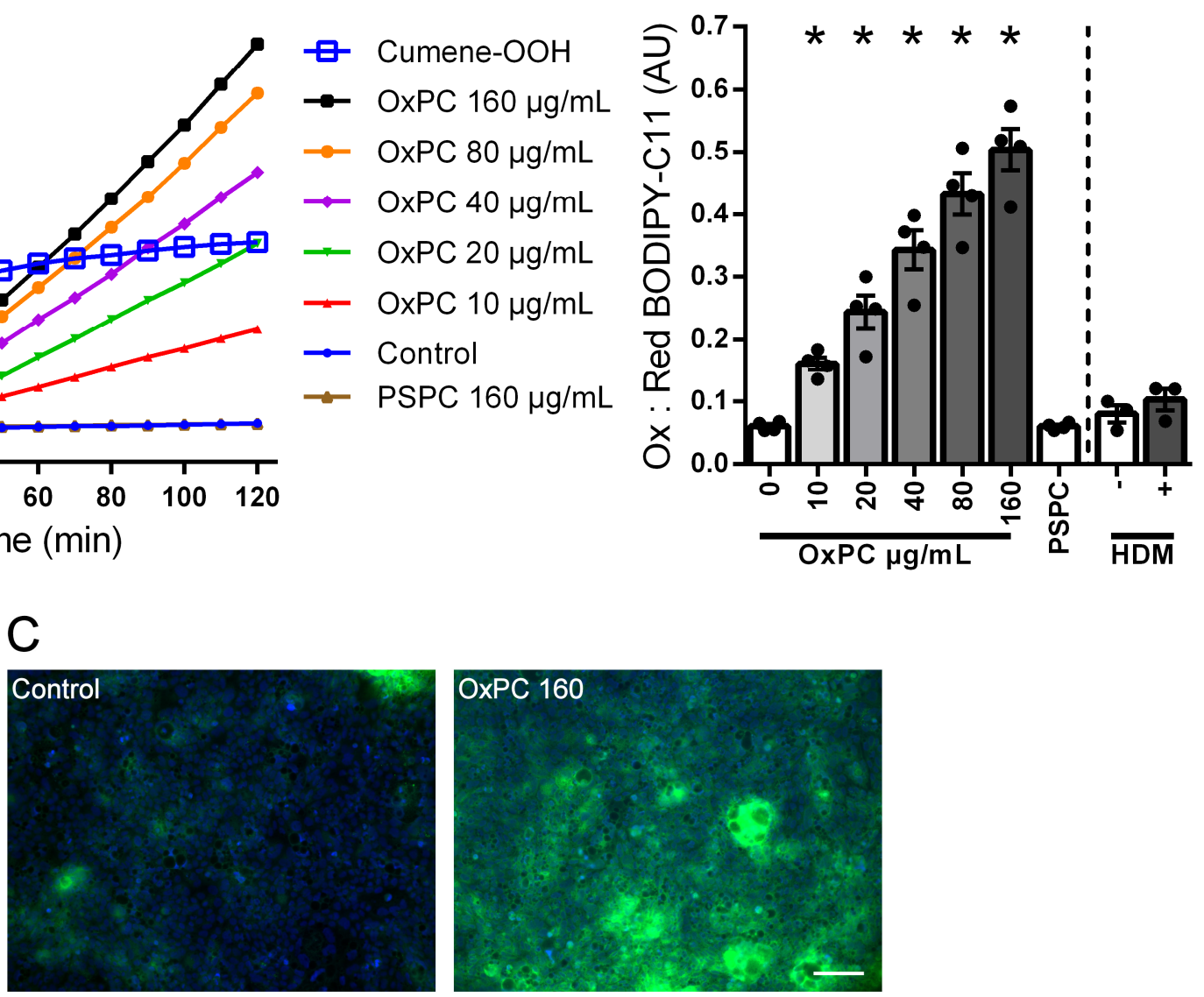

Figure 7.

OxPC induce time- (A) and dose-dependent (B) generation of lipid peroxides in Calu-3 cells $(p<0.0001, n=4)$. The effect of HDM was modest in comparison and not statistically significant $(p=0.0522, n=3)$. In contrast to general ROS, $10 \mathrm{mM}$ NAC could only partially reverse lipid peroxidation ( $C ; p=0.0001, n=7)$. Assessing lipid peroxidation by an alternative histological technique (D) confirms significant accumulation that did not appear to be localized to any specific cell membrane or organelle. * represents significant difference from the $0 \mu \mathrm{g} / \mathrm{mL}$ OxPC control condition (B) and from the OxPC $160 \mu \mathrm{g} / \mathrm{mL}$ condition (C). Scale bar is $100 \mu \mathrm{m}$. 
bioRxiv preprint doi: https://doi.org/10.1101/823666; this version posted October 26, 2020. The copyright holder for this preprint (which was not certified by peer review) is the author/funder, who has granted bioRxiv a license to display the preprint in perpetuity. It is made available under Oxidized phosphatidylcholines impair epithelial barrier

A

B
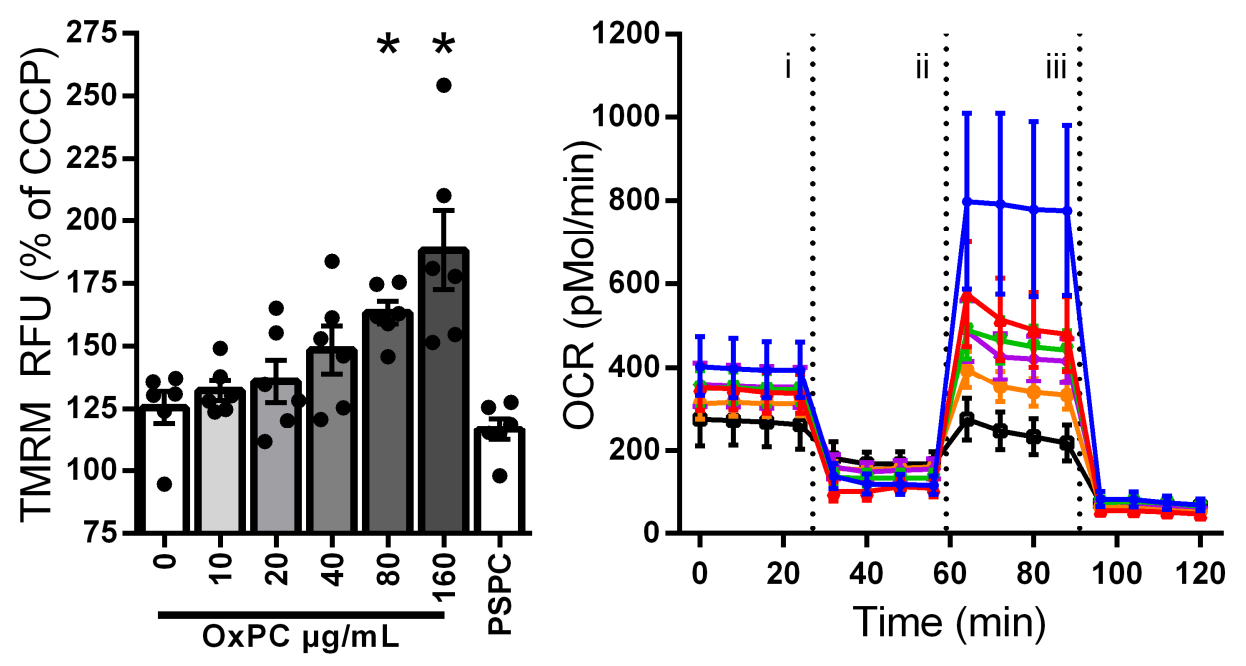

$\rightarrow$ Control

$\rightarrow$ OxPC $10 \mu \mathrm{g} / \mathrm{mL}$

$\rightarrow \quad$ OxPC $20 \mu \mathrm{g} / \mathrm{mL}$

$\rightarrow \quad$ OxPC $40 \mu \mathrm{g} / \mathrm{mL}$

$\rightarrow$ OxPC $80 \mu \mathrm{g} / \mathrm{mL}$

$\rightarrow$ OxPC $160 \mu \mathrm{g} / \mathrm{mL}$

C

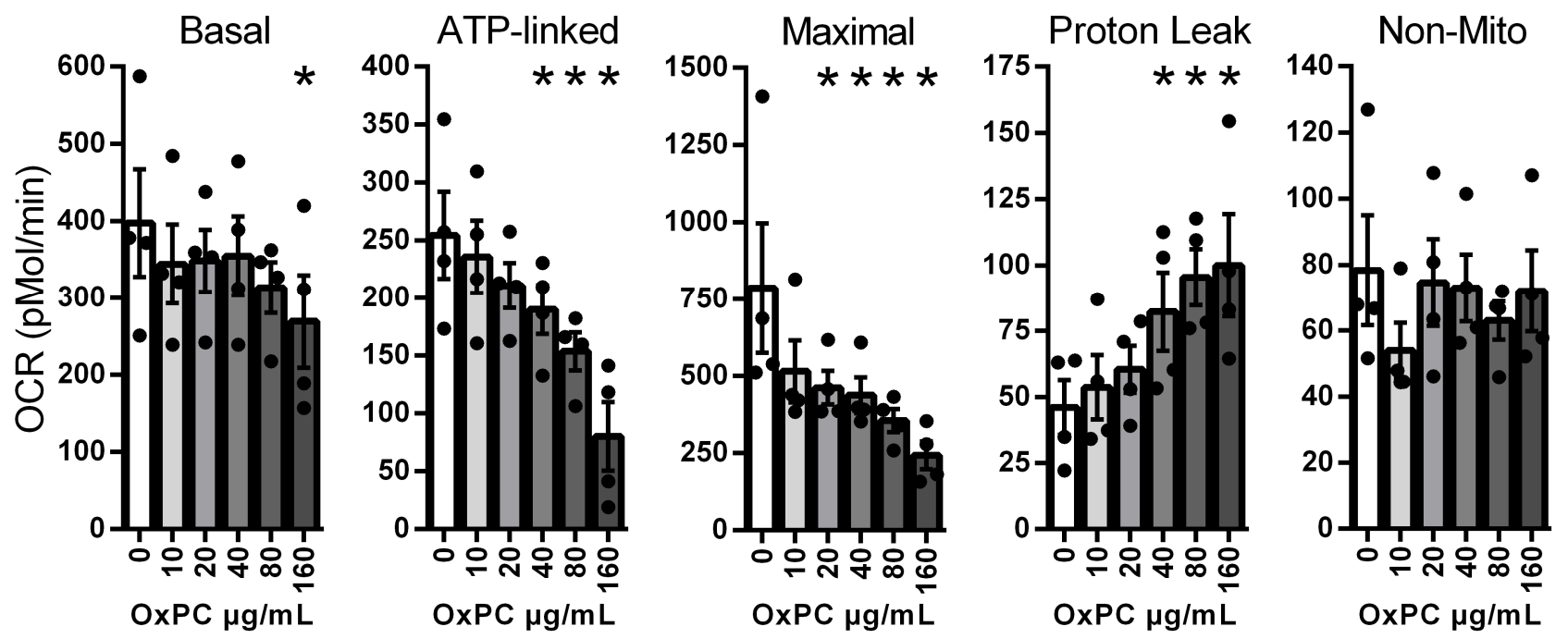

Figure 8.

OxPC induce dose-dependent increase in TMRM fluorescence, indicative of mitochondrial membrane hyperpolarisation $(A ; p<0.0001, n=6)$. Reductions in OCR (interaction $p=0.0001$, time $p<0.0001,0 x P C p<0.0001$, $n=4)$ are apparent during mitochondrial stress tests ( $B$; $i=0$ ligomycin, $i i=F C C P$, iii=rotenone/antimycin- $A$ ), and calculation of distinct metabolic parameters (C) reveals dose-dependent reductions in basal $(p=0.0165)$, ATPlinked $(p<0.0001)$ and maximal respiration $(p=0.0013)$, dose-dependent increases in proton leak $(p=0.0002)$, but no change in non-mitochondrial respiration ( $p=0.0952)$. These combined responses are indicative of mitochondrial dysfunction in response to OxPC challenge. * represents significant difference from the $0 \mu \mathrm{g} / \mathrm{mL}$ OxPC control condition. 
bioRxiv preprint doi: https://doi.org/10.1101/823666; this version posted October 26, 2020. The copyright holder for this preprint (which was not certified by peer review) is the author/funder, who has granted bioRxiv a license to display the preprint in perpetuity. It is made available under aCC-BY-ND 4.0 International license.
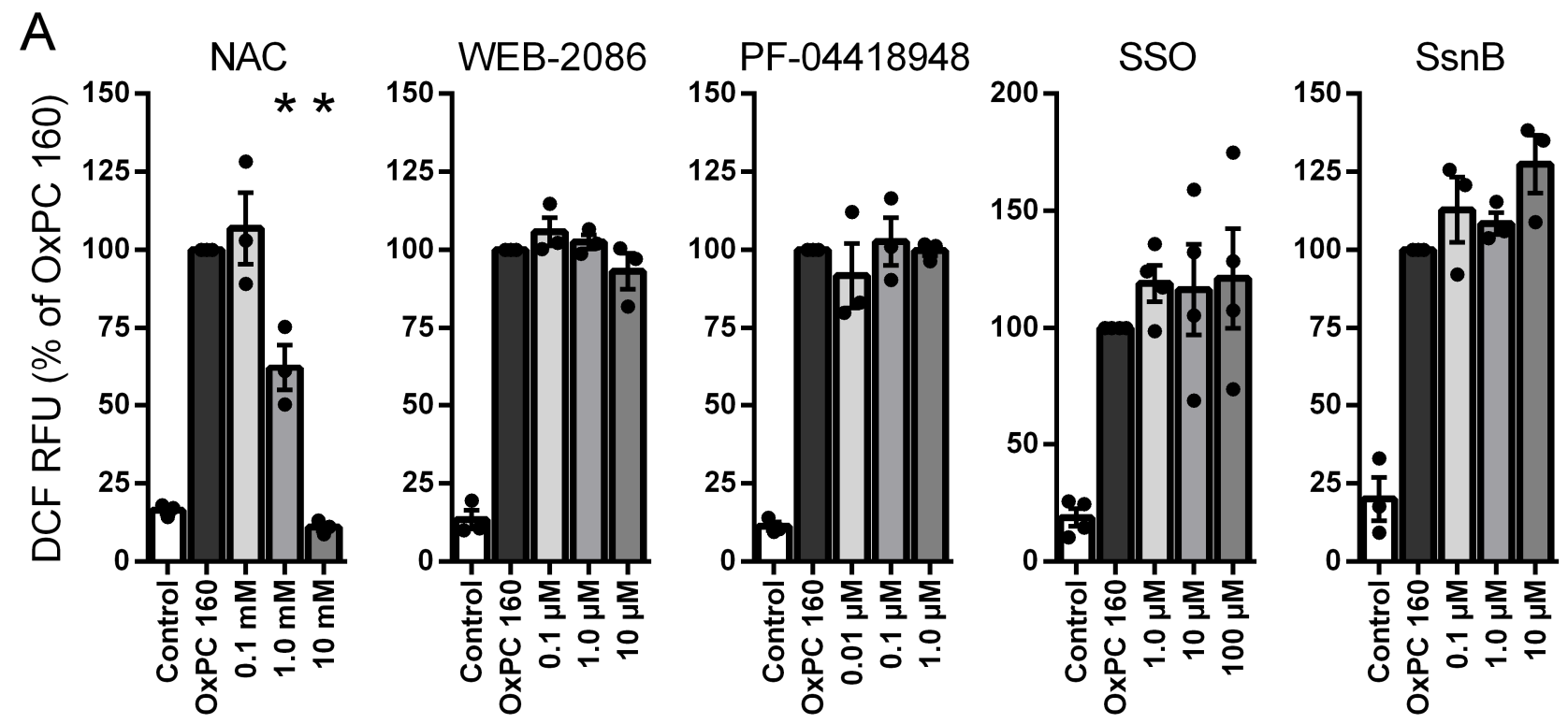

B

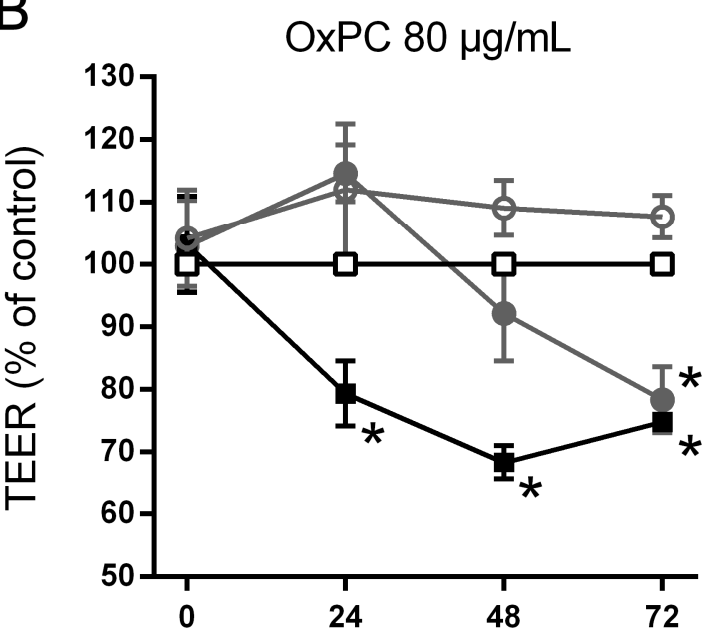

Time after OxPC exposure (h)

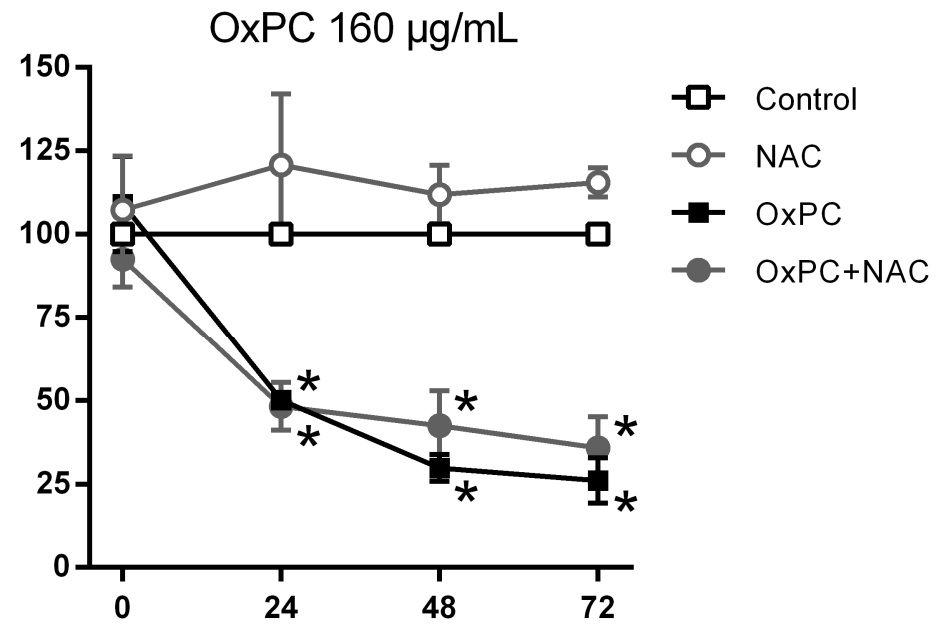

Time after OxPC exposure (h)
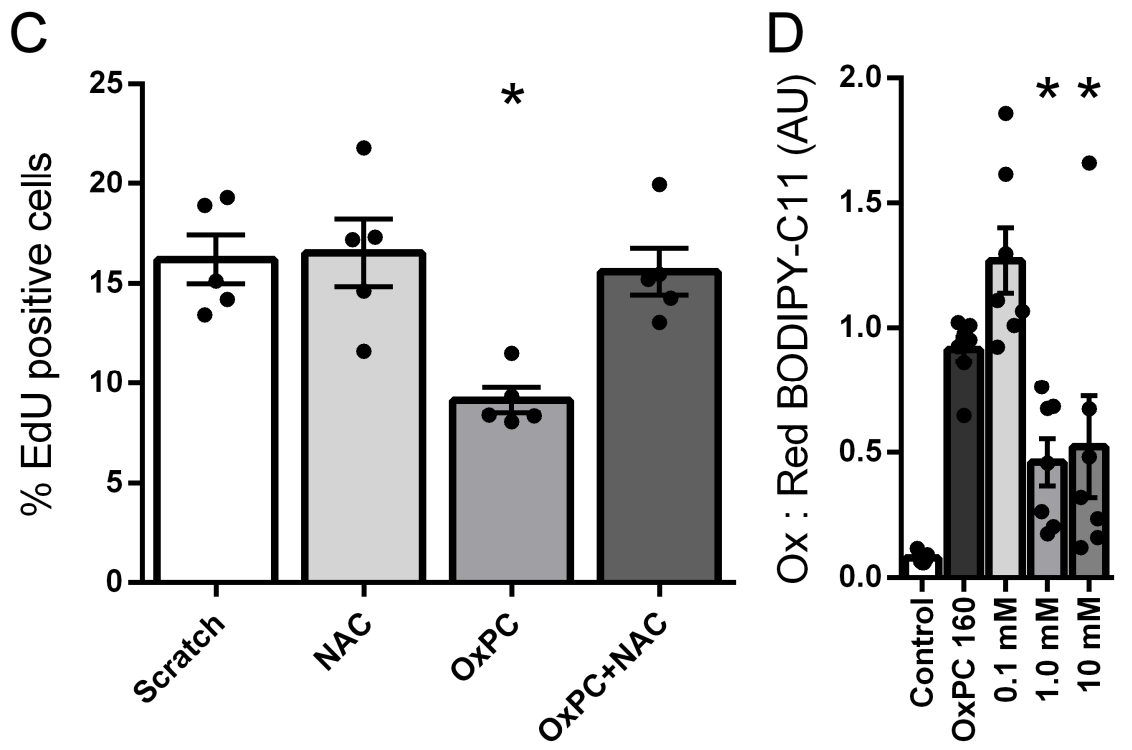
bioRxiv preprint doi: https://doi.org/10.1101/823666; this version posted October 26, 2020. The copyright holder for this preprint (which was not certified by peer review) is the author/funder, who has granted bioRxiv a license to display the preprint in perpetuity. It is made available under Oxidized phosphatidylcholines impair epithelial barrier

\section{Figure 9.}

General ROS accumulation induced by OxPC in Calu-3 cells could be abrogated by the antioxidant NAC (A; $p=0.0004, n=3$ ). However, inhibitors of established OxPC receptors PAFR (WEB-2086; $p=0.1179, n=3)$, EP2 (PF04418948; $p=0.5317, n=3$ ), CD36 (SSO; $p=0.7256, n=4)$ and TLR2/4 (SsnB; $p=0.1664, n=3$ ) each had no effect. Subsequently, $1 \mathrm{mM}$ NAC was shown to temporarily delay barrier dysfunction induced by $80 \mu \mathrm{g} / \mathrm{mL}$ OxPC (B; interaction $p=0.0003$, time $p=0.0013, \operatorname{OxPC} p<0.0001, n=10$ ) but not $160 \mu \mathrm{g} / \mathrm{mL}$ OxPC (interaction $p<0.0001$, time $p<0.0001$, OxPC $p<0.0001, n=5)$. Similarly, the reduction in DNA synthesis observed with $80 \mu \mathrm{g} / \mathrm{mL} O x P C$ was not seen when co-treated with $1 \mathrm{mM} \mathrm{NAC}(C ; p=0.0054, n=5)$, but lipid peroxidation persisted even at supramaximal NAC doses ( $D ; p=0.0001, n=7)$. * represents significant difference (i.e., inhibition) from the OxPC $160 \mu \mathrm{g} / \mathrm{mL}$ condition (A and D) or from the $0 \mu \mathrm{g} / \mathrm{mL}$ OxPC control condition (B-D). Untreated Controls are shown for reference in $A$ and $D$ but are not included in the statistics. 
bioRxiv preprint doi: https://doi.org/10.1101/823666; this version posted October 26, 2020. The copyright holder for this preprint (which was not certified by peer review) is the author/funder, who has granted bioRxiv a license to display the preprint in perpetuity. It is made available under Oxidized phosphatidylcholines impair epithelial barrier aCC-BY-ND 4.0 International license.

\section{REFERENCES}

1. Aliyali M, Poorhasan Amiri A, Sharifpoor A, and Zalli F. Effects of $\mathrm{N}$-acetylcysteine on asthma exacerbation. Iran J Allergy Asthma Immunol 9: 103-109, 2010.

2. Ayala A, Munoz MF, and Arguelles S. Lipid peroxidation: production, metabolism, and signaling mechanisms of malondialdehyde and 4-hydroxy-2-nonenal. Oxid Med Cell Longev 2014: 360438, 2014.

3. Birukova AA, Starosta V, Tian X, Higginbotham K, Koroniak L, Berliner JA, and Birukov KG. Fragmented oxidation products define barrier disruptive endothelial cell response to OxPAPC. Transl Res 161: 495-504, 2013.

4. Bochkov VN, Oskolkova OV, Birukov KG, Levonen AL, Binder CJ, and Stockl J. Generation and biological activities of oxidized phospholipids. Antioxid Redox Signal 12: 1009-1059, 2010.

5. Buchert $\mathbf{M}$, Turksen $\mathbf{K}$, and Hollande $\mathbf{F}$. Methods to examine tight junction physiology in cancer stem cells: TEER, paracellular permeability, and dilution potential measurements. Stem Cell Rev 8: 1030-1034, 2012.

6. Buland JR, Wasserloos KJ, Tyurin VA, Tyurina YY, Amoscato AA, Mallampalli RK, Chen BB, Zhao J, Zhao Y, Ofori-Acquah S, Kagan VE, and Pitt BR. Biosynthesis of oxidized lipid mediators via lipoproteinassociated phospholipase A2 hydrolysis of extracellular cardiolipin induces endothelial toxicity. Am J Physiol Lung Cell Mol Physiol 311: L303-316, 2016.

7. Chivers JE, Cambridge LM, Catley MC, Mak JC, Donnelly LE, Barnes PJ, and Newton R. Differential effects of RU486 reveal distinct mechanisms for glucocorticoid repression of prostaglandin E release. Eur $\mathrm{J}$ Biochem 271: 4042-4052, 2004.

8. Comhair SA, Ricci KS, Arroliga M, Lara AR, Dweik RA, Song W, Hazen SL, Bleecker ER, Busse WW, Chung KF, Gaston B, Hastie A, Hew M, Jarjour N, Moore W, Peters S, Teague WG, Wenzel SE, and Erzurum SC. Correlation of systemic superoxide dismutase deficiency to airflow obstruction in asthma. Am J Respir Crit Care Med 172: 306-313, 2005.

9. Cosio BG, Mann B, Ito K, Jazrawi E, Barnes PJ, Chung KF, and Adcock IM. Histone acetylase and deacetylase activity in alveolar macrophages and blood mononocytes in asthma. Am J Respir Crit Care Med 170: 141-147, 2004.

10. Cruz D, Watson AD, Miller CS, Montoya D, Ochoa MT, Sieling PA, Gutierrez MA, Navab M, Reddy ST, Witztum JL, Fogelman AM, Rea TH, Eisenberg D, Berliner J, and Modlin RL. Host-derived oxidized phospholipids and HDL regulate innate immunity in human leprosy. J Clin Invest 118: 2917-2928, 2008.

11. De Raeve HR, Thunnissen FB, Kaneko FT, Guo FH, Lewis M, Kavuru MS, Secic M, Thomassen MJ, and Erzurum SC. Decreased Cu,Zn-SOD activity in asthmatic airway epithelium: correction by inhaled corticosteroid in vivo. Am J Physiol 272: L148-154, 1997.

12. Ercan H, Birben E, Dizdar EA, Keskin O, Karaaslan C, Soyer OU, Dut R, Sackesen C, Besler T, and Kalayci O. Oxidative stress and genetic and epidemiologic determinants of oxidant injury in childhood asthma. $J$ Allergy Clin Immunol 118: 1097-1104, 2006.

13. Erridge C, Kennedy S, Spickett CM, and Webb DJ. Oxidized phospholipid inhibition of toll-like receptor (TLR) signaling is restricted to TLR2 and TLR4: roles for CD14, LPS-binding protein, and MD2 as targets for specificity of inhibition. J Biol Chem 283: 24748-24759, 2008.

14. Erzurum SC. New Insights in Oxidant Biology in Asthma. Ann Am Thorac Soc 13 Suppl 1: S35-39, 2016.

15. Ezerina D, Takano Y, Hanaoka K, Urano Y, and Dick TP. N-Acetyl Cysteine Functions as a Fast-Acting Antioxidant by Triggering Intracellular H2S and Sulfane Sulfur Production. Cell Chem Biol 25: 447-459 e444, 2018.

16. Fatani SH. Biomarkers of oxidative stress in acute and chronic bronchial asthma. J Asthma 51: 578-584, 2014.

17. Feinstein MB, and Schleimer RP. Regulation of the action of hydrocortisone in airway epithelial cells by 11beta-hydroxysteroid dehydrogenase. Am J Respir Cell Mol Biol 21: 403-408, 1999.

18. Fitzpatrick AM, Teague WG, Holguin F, Yeh M, Brown LA, and Severe Asthma Research P. Airway glutathione homeostasis is altered in children with severe asthma: evidence for oxidant stress. J Allergy Clin Immunol 123: 146-152 e148, 2009. 
bioRxiv preprint doi: https://doi.org/10.1101/823666; this version posted October $26,2020$. The copyright holder for this preprint (which was not certified by peer review) is the author/funder, who has granted bioRxiv a license to display the preprint in perpetuity. It is made available under Oxidized phosphatidylcholines impair epithelial barrier aCC-BY-ND 4.0 International license.

19. Fornace AJ, Jr., Alamo I, Jr., Hollander MC, and Lamoreaux E. Ubiquitin mRNA is a major stressinduced transcript in mammalian cells. Nucleic Acids Res 17: 1215-1230, 1989.

20. Fruhwirth GO, Loidl A, and Hermetter A. Oxidized phospholipids: from molecular properties to disease. Biochim Biophys Acta 1772: 718-736, 2007.

21. Furnkranz A, Schober A, Bochkov VN, Bashtrykov P, Kronke G, Kadl A, Binder BR, Weber C, and Leitinger N. Oxidized phospholipids trigger atherogenic inflammation in murine arteries. Arterioscler Thromb Vasc Biol 25: 633-638, 2005.

22. Gargalovic PS, Imura M, Zhang B, Gharavi NM, Clark MJ, Pagnon J, Yang WP, He A, Truong A, Patel S, Nelson SF, Horvath S, Berliner JA, Kirchgessner TG, and Lusis AJ. Identification of inflammatory gene modules based on variations of human endothelial cell responses to oxidized lipids. Proc Natl Acad Sci U S A 103: 1274112746, 2006.

23. Giovannini C, Matarrese P, Scazzocchio B, Sanchez M, Masella R, and Malorni W. Mitochondria hyperpolarization is an early event in oxidized low-density lipoprotein-induced apoptosis in Caco-2 intestinal cells. FEBS Lett 523: 200-206, 2002.

24. Hackett TL, Singhera GK, Shaheen F, Hayden P, Jackson GR, Hegele RG, Van Eeden S, Bai TR, Dorscheid DR, and Knight DA. Intrinsic phenotypic differences of asthmatic epithelium and its inflammatory responses to respiratory syncytial virus and air pollution. Am J Respir Cell Mol Biol 45: 1090-1100, 2011.

25. Heijink IH, Nawijn MC, and Hackett TL. Airway epithelial barrier function regulates the pathogenesis of allergic asthma. Clin Exp Allergy 44: 620-630, 2014.

26. Hellemans J, Mortier G, De Paepe A, Speleman F, and Vandesompele J. qBase relative quantification framework and software for management and automated analysis of real-time quantitative PCR data. Genome Biol 8: R19, 2007.

27. Hernandez ML, Wagner JG, Kala A, Mills K, Wells HB, Alexis NE, Lay JC, Jiang Q, Zhang H, Zhou H, and Peden DB. Vitamin E, gamma-tocopherol, reduces airway neutrophil recruitment after inhaled endotoxin challenge in rats and in healthy volunteers. Free Radic Biol Med 60: 56-62, 2013.

28. Holgate ST. Epithelium dysfunction in asthma. J Allergy Clin Immunol 120: 1233-1244; quiz 1245-1236, 2007.

29. Holgate ST, Davies DE, Puddicombe S, Richter A, Lackie P, Lordan J, and Howarth P. Mechanisms of airway epithelial damage: epithelial-mesenchymal interactions in the pathogenesis of asthma. Eur Respir J Suppl 44: 24s-29s, 2003.

30. Ito K, Hanazawa T, Tomita K, Barnes PJ, and Adcock IM. Oxidative stress reduces histone deacetylase 2 activity and enhances IL-8 gene expression: role of tyrosine nitration. Biochem Biophys Res Commun 315: 240245, 2004.

31. Jha A. Effect of simvastatin on airway inflammation, remodelling and hyperreactivity in a house dust mite challenged murine model of allergic asthma. PhD thesis available at http://hdl.handle.net/1993/32888: 2018.

32. Kamada F, Mashimo Y, Inoue H, Shao C, Hirota T, Doi S, Kameda M, Fujiwara H, Fujita K, Enomoto T, Sasaki S, Endo H, Takayanagi R, Nakazawa C, Morikawa T, Morikawa M, Miyabayashi S, Chiba Y, Tamura G, Shirakawa T, Matsubara Y, Hata A, Tamari M, and Suzuki Y. The GSTP1 gene is a susceptibility gene for childhood asthma and the GSTM1 gene is a modifier of the GSTP1 gene. Int Arch Allergy Immunol 144: 275-286, 2007.

33. Karki P, and Birukov KG. Lipid mediators in the regulation of endothelial barriers. Tissue Barriers 6 : e1385573, 2018.

34. Lee S, Birukov KG, Romanoski CE, Springstead JR, Lusis AJ, and Berliner JA. Role of phospholipid oxidation products in atherosclerosis. Circ Res 111: 778-799, 2012.

35. Lee S, Li R, Kim B, Palvolgyi R, Ho T, Yang QZ, Xu J, Szeto WL, Honda H, and Berliner JA. Ox-PAPC activation of PMET system increases expression of heme oxygenase-1 in human aortic endothelial cell. J Lipid Res 50: 265-274, 2009. 
bioRxiv preprint doi: https://doi.org/10.1101/823666; this version posted October 26,2020 . The copyright holder for this preprint (which was not certified by peer review) is the author/funder, who has granted bioRxiv a license to display the preprint in perpetuity. It is made available under Oxidized phosphatidylcholines impair epithelial barrier aCC-BY-ND 4.0 International license.

36. Lee YH, Lai CL, Hsieh SH, Shieh CC, Huang LM, and Wu-Hsieh BA. Influenza A virus induction of oxidative stress and MMP-9 is associated with severe lung pathology in a mouse model. Virus Res 178: 411422, 2013.

37. Li LB, Leung DY, Martin RJ, and Goleva E. Inhibition of histone deacetylase 2 expression by elevated glucocorticoid receptor beta in steroid-resistant asthma. Am J Respir Crit Care Med 182: 877-883, 2010.

38. Masuyama K, Morishima Y, Ishii Y, Nomura A, Sakamoto T, Kimura T, Mochizuki M, Uchida Y, and Sekizawa K. Sputum E-cadherin and asthma severity. J Allergy Clin Immunol 112: 208-209, 2003.

39. Mayr JA. Lipid metabolism in mitochondrial membranes. J Inherit Metab Dis 38: 137-144, 2015.

40. Oehler B, Kistner K, Martin C, Schiller J, Mayer R, Mohammadi M, Sauer RS, Filipovic MR, Nieto FR, Kloka J, Pflucke D, Hill K, Schaefer M, Malcangio M, Reeh PW, Brack A, Blum R, and Rittner HL. Inflammatory pain control by blocking oxidized phospholipid-mediated TRP channel activation. Sci Rep 7: 5447, 2017.

41. Pascoe CD, Jha A, Ryu MH, Ragheb M, Vaghasiya J, Basu S, Stelmack GL, Srinathan S, Kidane B, Kindrachuk J, O'Byrne PM, Gauvreau GM, Ravandi A, Carlsten C, and Halayko AJ. Allergen inhalation generates pro-inflammatory oxidised phosphatidylcholine associated with airway dysfunction. European Respiratory Journal 2000839, 2020.

42. Patel BD, Welch AA, Bingham SA, Luben RN, Day NE, Khaw KT, Lomas DA, and Wareham NJ. Dietary antioxidants and asthma in adults. Thorax 61: 388-393, 2006.

43. Peh HY, Ho WE, Cheng C, Chan TK, Seow AC, Lim AY, Fong CW, Seng KY, Ong CN, and Wong WS. Vitamin E Isoform gamma-Tocotrienol Downregulates House Dust Mite-Induced Asthma. J Immunol 195: 437444, 2015.

44. Que X, Hung MY, Yeang C, Gonen A, Prohaska TA, Sun X, Diehl C, Maatta A, Gaddis DE, Bowden K, Pattison J, MacDonald JG, Yla-Herttuala S, Mellon PL, Hedrick CC, Ley K, Miller YI, Glass CK, Peterson KL, Binder $\mathrm{CJ}$, Tsimikas S, and Witztum JL. Oxidized phospholipids are proinflammatory and proatherogenic in hypercholesterolaemic mice. Nature 558: 301-306, 2018.

45. RiedI MA, and Nel AE. Importance of oxidative stress in the pathogenesis and treatment of asthma. Curr Opin Allergy Clin Immunol 8: 49-56, 2008.

46. Ruijter JM, Ramakers C, Hoogaars WM, Karlen Y, Bakker O, van den Hoff MJ, and Moorman AF.

Amplification efficiency: linking baseline and bias in the analysis of quantitative PCR data. Nucleic Acids Res 37: e45, 2009.

47. Rushworth GF, and Megson IL. Existing and potential therapeutic uses for N-acetylcysteine: the need for conversion to intracellular glutathione for antioxidant benefits. Pharmacol Ther 141: 150-159, 2014.

48. Sackesen C, Ercan H, Dizdar E, Soyer O, Gumus P, Tosun BN, Buyuktuncer Z, Karabulut E, Besler T, and Kalayci O. A comprehensive evaluation of the enzymatic and nonenzymatic antioxidant systems in childhood asthma. J Allergy Clin Immunol 122: 78-85, 2008.

49. Sahiner UM, Birben E, Erzurum S, Sackesen C, and Kalayci O. Oxidative stress in asthma. World Allergy Organ J 4: 151-158, 2011.

50. Solati Z, Edel AL, Shang Y, O K, and Ravandi A. Oxidized phosphatidylcholines are produced in renal ischemia reperfusion injury. PLoS One 13: e0195172, 2018.

51. Starosta V, Wu T, Zimman A, Pham D, Tian X, Oskolkova O, Bochkov V, Berliner JA, Birukova AA, and Birukov KG. Differential regulation of endothelial cell permeability by high and low doses of oxidized 1palmitoyl-2-arachidonyl-sn-glycero-3-phosphocholine. Am J Respir Cell Mol Biol 46: 331-341, 2012.

52. Stevens PT, Kicic A, Sutanto EN, Knight DA, and Stick SM. Dysregulated repair in asthmatic paediatric airway epithelial cells: the role of plasminogen activator inhibitor-1. Clin Exp Allergy 38: 1901-1910, 2008.

53. Tamer L, Calikoglu M, Ates NA, Yildirim H, Ercan B, Saritas E, Unlu A, and Atik U. Glutathione-Stransferase gene polymorphisms (GSTT1, GSTM1, GSTP1) as increased risk factors for asthma. Respirology 9: 493-498, 2004.

54. Tenero L, Piazza M, Zanoni L, Bodini A, Peroni D, and Piacentini GL. Antioxidant supplementation and exhaled nitric oxide in children with asthma. Allergy Asthma Proc 37: e8-13, 2016. 
bioRxiv preprint doi: https://doi.org/10.1101/823666; this version posted October 26, 2020. The copyright holder for this preprint (which was not certified by peer review) is the author/funder, who has granted bioRxiv a license to display the preprint in perpetuity. It is made available under Oxidized phosphatidylcholines impair epithelial barrier aCC-BY-ND 4.0 International license.

55. Van Lenten BJ, Wagner AC, Navab M, Anantharamaiah GM, Hui EK, Nayak DP, and Fogelman AM. D$4 F$, an apolipoprotein A-I mimetic peptide, inhibits the inflammatory response induced by influenza $A$ infection of human type II pneumocytes. Circulation 110: 3252-3258, 2004.

56. Vandesompele J, De Preter K, Pattyn F, Poppe B, Van Roy N, De Paepe A, and Speleman F. Accurate normalization of real-time quantitative RT-PCR data by geometric averaging of multiple internal control genes. Genome Biol 3: RESEARCH0034, 2002.

57. Walton KA, Hsieh X, Gharavi N, Wang S, Wang G, Yeh M, Cole AL, and Berliner JA. Receptors involved in the oxidized 1-palmitoyl-2-arachidonoyl-sn-glycero-3-phosphorylcholine-mediated synthesis of interleukin-8. A role for Toll-like receptor 4 and a glycosylphosphatidylinositol-anchored protein. J Biol Chem 278: 2966129666, 2003.

58. West AR, Zaman N, Cole DJ, Walker MJ, Legant WR, Boudou T, Chen CS, Favreau JT, Gaudette GR, Cowley EA, and Maksym GN. Development and characterization of a 3D multicell microtissue culture model of airway smooth muscle. Am J Physiol Lung Cell Mol Physiol 304: L4-16, 2013.

59. Wood LG, Garg ML, Smart JM, Scott HA, Barker D, and Gibson PG. Manipulating antioxidant intake in asthma: a randomized controlled trial. Am J Clin Nutr 96: 534-543, 2012.

60. Yang Y, Cheng JZ, Singhal SS, Saini M, Pandya U, Awasthi S, and Awasthi YC. Role of glutathione Stransferases in protection against lipid peroxidation. Overexpression of hGSTA2-2 in K562 cells protects against hydrogen peroxide-induced apoptosis and inhibits JNK and caspase 3 activation. J Biol Chem 276: 19220-19230, 2001.

61. Ye J, Coulouris G, Zaretskaya I, Cutcutache I, Rozen S, and Madden TL. Primer-BLAST: a tool to design target-specific primers for polymerase chain reaction. BMC Bioinformatics 13: 134, 2012.

62. Yeang C, Hasanally D, Que X, Hung MY, Stamenkovic A, Chan D, Chaudhary R, Margulets V, Edel AL, Hoshijima M, Gu Y, Bradford W, Dalton N, Miu P, Cheung DY, Jassal DS, Pierce GN, Peterson KL, Kirshenbaum LA, Witztum JL, Tsimikas S, and Ravandi A. Reduction of myocardial ischaemia-reperfusion injury by inactivating oxidized phospholipids. Cardiovasc Res 115: 179-189, 2019.

63. Zahm JM, Kaplan H, Herard AL, Doriot F, Pierrot D, Somelette P, and Puchelle E. Cell migration and proliferation during the in vitro wound repair of the respiratory epithelium. Cell Motil Cytoskeleton 37: 33-43, 1997.

64. Zaidman NA, Panoskaltsis-Mortari A, and O'Grady SM. Differentiation of human bronchial epithelial cells: role of hydrocortisone in development of ion transport pathways involved in mucociliary clearance. $\mathrm{Am} J$ Physiol Cell Physiol 311: C225-236, 2016.

65. Zuo L, He F, Sergakis GG, Koozehchian MS, Stimpfl JN, Rong Y, Diaz PT, and Best TM. Interrelated role of cigarette smoking, oxidative stress, and immune response in COPD and corresponding treatments. Am J Physiol Lung Cell Mol Physiol 307: L205-218, 2014.

66. Zuo L, Otenbaker NP, Rose BA, and Salisbury KS. Molecular mechanisms of reactive oxygen speciesrelated pulmonary inflammation and asthma. Mol Immunol 56: 57-63, 2013. 